\title{
Microfinance and households coping with HIV/AIDS in Zimbabwe: An exploratory study
}

Carolyn Barnes

Erica Keogh

Nontokozo Nemarundwe

Loveness Nyikahadzoi

Ellen Weiss

Follow this and additional works at: https://knowledgecommons.popcouncil.org/departments_sbsr-hiv

Part of the Demography, Population, and Ecology Commons, Health Economics Commons, Health Policy Commons, Immune System Diseases Commons, International Public Health Commons, Medicine and Health Commons, Public Health Education and Promotion Commons, and the Virus Diseases Commons How does access to this work benefit you? Let us know!

\section{Recommended Citation}

Barnes, Carolyn, Erica Keogh, Nontokozo Nemarundwe, Loveness Nyikahadzoi, and Ellen Weiss. 2003. "Microfinance and households coping with HIV/AIDS in Zimbabwe: An exploratory study," Horizons Final Report. Washington, DC: Population Council. 


\section{Hprizons $\Lambda$}

\section{Microfinance and Households Coping with HIV/AIDS in Zimbabwe: An Exploratory Study}
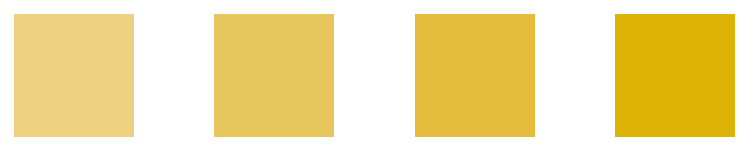

Management Systems International

The University of Zimbabwe Horizons Program 


\title{
Microfinance and Households Coping with HIV/AIDS in Zimbabwe: An Exploratory Study
}

\author{
Carolyn Barnes \\ Management Systems International
}

In association with Erica Keogh, Nontokozo Nemarundwe, and Loveness Nyikahadzoi of the University of Zimbabwe, and

Ellen Weiss of Horizons/International Center for Research on Women 


\section{Acknowledgments}

Many individuals have contributed to the successful completion of this report and the associated AIMS assessment. I am grateful to each of them. The work in Zimbabwe was dependent upon the high level of cooperation given the research team by the officers and staff of Zambuko Trust. In particular, I would like to thank Tawanda Sibanda, acting executive managing director of Zambuko, who provided advice and assistance. I would also like to acknowledge the cooperation of David Kombanie, former executive managing director of Zambuko, and Zambuko's managers and staff in the Harare, Mutare, and Bulawayo regions. They willingly and cheerfully provided information about the program and its clients and permitted access to the files. Individuals at USAID/Zimbabwe also provided valuable support. In particular, the author appreciates the assistance given by Tichaona Mushayandevu, Patrick Osewe, and Carl Henn.

Erica Keogh assembled and supervised the survey field team. In addition, she was responsible for data entry and cleaning, and conducted the data analysis. Nontokozo Nemarundwe organized and conducted the focus group sessions with clients. She was assisted by Loveness Nyikahadzoi. At the September 2001 discussion forum in Harare, the Zimbabwean team facilitated sessions and took notes. I am extremely grateful to them for their hard work and commitment to the study.

A special thanks goes to Paurvi Bhatt, formerly with USAID's health office, who provided encouragement, advice, and comments on the draft report. Throughout the AIMS and Horizons studies, Monique Cohen of USAID's Microenterprise Development Office and Jennefer Sebstad gave thoughtful guidance. Joan Parker, Simel Esim, Martin Hanratty, and Naomi Rutenberg kindly provided review comments on an earlier version of this report.

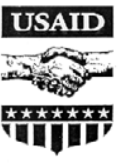

This study was supported by the Horizons Program, which is implemented by the Population Council in collaboration with the International Center for Research on Women, International HIV/AIDS Alliance, Program for Appropriate Technology in Health, Tulane University, Family Health International, and Johns

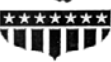
Hopkins University. Horizons is funded by the U.S. Agency for International Development, under the terms of HRN-A-00-97-00012-00. Complementary funding was also provided by the Microenterprise Impact Project (PCE-0406-C-00-5036-00) of USAID's Office of Microenterprise Development and USAID's Africa Bureau. The opinions expressed herein are those of the authors and do not necessarily reflect the views of the U.S. Agency for International Development.

Published in June 2003.

\footnotetext{
12 Population Council The Population Council is an international, nonprofit, nongovernmental institution that generations around the world and to help achieve a humane, equitable, and sustainable balance between people and resources. The Council conducts biomedical, social science, and public health research and helps build research capacities in developing countries. Established in 1952, the Council is governed by an international board of trustees. Its New York headquarters supports a global network of regional and country offices.
}

Copyright (C) 2003 The Population Council Inc. 


\section{Table of Contents}

Executive Summary

Introduction 7

$\begin{array}{ll}\text { Objective } & 7\end{array}$

$\begin{array}{ll}\text { Scope of the study } & 8\end{array}$

Key contextual factors $\quad 9$

$\begin{array}{ll}\text { Zambuko Trust } & 10\end{array}$

Approach and Comparison Groups 11

$\begin{array}{ll}\text { Definitions of key terms } & 11\end{array}$

Mixed methods 11

$\begin{array}{ll}\text { Statistical methods } & 12\end{array}$

$\begin{array}{ll}\text { Comparison groups } & 12\end{array}$

$\begin{array}{ll}\text { Characteristics of survey respondents } & 13\end{array}$

$\begin{array}{ll}\text { Intensity of participation in Zambuko's program } & 14\end{array}$

Key Findings $\quad 15$

To what extent does HIV/AIDS affect microentrepreneurs and their households? $\quad 15$

$\begin{array}{ll}\text { What is the economic effect of HIV/AIDS on households? } & 16\end{array}$

$\begin{array}{ll}\text { Do HIV-affected clients differ from HIV-affected non-clients? } & 18\end{array}$

Does participation in an MFI program mitigate the economic impact of HIV/AIDS 20 on households? 
How have chronic illness and death affected the operation of MFIs and

participation in MFI programs?

What measures might be taken to mitigate the potential negative impact of

HIV/AIDS on microentrepreneurs and MFIs?

What actions do other key stakeholders suggest to address the situation?

Implications of the Findings

$\begin{array}{ll}\text { Macroeconomic conditions } & 27\end{array}$

$\begin{array}{ll}\text { Legal status of MFIs } & 27\end{array}$

Denial of HIV/AIDS 27

$\begin{array}{ll}\text { Networks } & 27\end{array}$

$\begin{array}{ll}\text { Partnerships } & 28\end{array}$

Estimating HIV-affectedness and its impact on organizations 28

Measures to ameliorate the impact of HIV/AIDS on MFIs 28

Increasing households' ability to respond to negative economic influences 29 of HIV/AIDS-affectedness

Measures to help HIV-affected persons 29

Additional studies 30

Appendixes 32

Appendix A: Summary of the key findings of the aims assessment of Zambuko 32

Appendix B: Summary of study design and methods 37

Appendix C: Additional tables 44

Appendix D: Suggestions from the forum on microfinance and households 56 coping with illness and death in Zimbabwe 


\section{Executive Summary}

The widespread prevalence of HIV/AIDS in sub-Saharan Africa adversely affects millions of households. In recent years, microfinance has been proposed as a strategy to help the households of microentrepreneurs respond to the negative economic impacts of HIV/AIDS. This attention to the potential role of microfinance builds upon earlier research that shows that microfinance institutions (MFIs) that charge commercial rates of interest and use sound business practices can become operationally self-sustainable (Christen 2000) and help improve the lives of the poor and vulnerable non-poor (Sebstad and Cohen 2001). This type of MFI generally offers small-sized loans, often combined with savings services. An MFI may also offer business management training, health and nutrition education, and other types of services.

This study, conducted in Zimbabwe, sought to better understand the relationship between a microfinance program, Zambuko Trust, and how microentrepreneurs' households cope with the impact of HIV/AIDS. The study also examined how HIV/AIDS is affecting Zambuko's operations and what MFIs can do to lessen the impact of HIV/AIDS on their clients and operations.

\section{Study Methodology}

The study involved reanalysis of survey data collected under USAID's Assessing the Impact of Microenterprises Services (AIMS) Project (Barnes 2001). The AIMS assessment focused on Zambuko Trust, a nongovernmental organization (NGO) that provides small-sized loans and business management training to Zimbabwean microentrepreneurs. The survey covered 338 Zambuko clients and 241 matched non-client microentrepreneurs who were interviewed in 1997 and re-interviewed in 1999. The non-client respondents were randomly selected among those who met Zambuko's basic eligibility criteria, ${ }^{1}$ and non-clients were matched with clients according to gender, enterprise sector, and neighborhood.

Because of the sensitivity of the topic and the difficulty of measuring directly whether households are affected by HIV/AIDS, proxy indicators were used to classify the survey respondent households as HIV-affected or non-affected. The proxy indictors included chronic illness of an adult household member, death of an adult household member, and absorption of orphans or sick persons into the household.

The respondents resided in Harare, Chitungweza, Bulawayo, and Mutare. The survey data were supplemented by focus groups in these same urban areas with 140 randomly selected Zambuko clients and with 33 Zambuko loan officers and branch managers in late 2000 and early 2001, and by interviews with senior managers of Zambuko. At a September 2001 forum in Harare,

\footnotetext{
${ }^{1}$ The individual must own an enterprise that is at least six months old, not be employed full-time elsewhere, and not have a loan for their enterprise from any other source.
} 


\section{Hgrizons}

representatives of MFIs, HIV/AIDS service organizations, and donor organizations in Zimbabwe discussed the implications of the findings.

\section{Country Context}

The macroeconomic and social environment influences circumstances, options, and choices of households and owners of microenterprises. The larger environment also influences the operations of MFIs.

Zimbabwe's annual inflation rate as measured by the Consumer Price Index (CPI) soared during the study period. In the 12 months after launching the survey in September 1997, the CPI rose 32 percent. Between September 1998 and September 1999, inflation was 70 percent, and the following year it was 62 percent.

The negative influence of the macroeconomic environment has been exacerbated by the high prevalence of HIV/AIDS in Zimbabwe. In 1999 an estimated one-quarter of Zimbabweans between 15 to 49 years old were infected with HIV (UNAIDS and WHO 2000).

\section{Zambuko Trust}

Zambuko is the largest microfinance program serving microentrepreneurs in Zimbabwe. Begun in 1992, it had branch offices in all of the major urban centers as well as key secondary towns by 1999. Its legal status as a money lender does not permit it to accept voluntary deposits.

Approximately 45 percent of its clients are traders, and 40 percent of its clients are engaged in manufacturing, such as knitting sweaters and sewing. The others are engaged in services, agriculture (livestock rearing and market gardens), and food preparation.

In 1997, the average Zambuko loan was Z\$2,537 (equivalent to US\$213) and carried a 32 percent per annum interest rate. In 2000, the average loan size was $Z \$ 10,162$ (equivalent to only US\$185, due to the decline in the value of the Zimbabwe dollar). By late 2000, the interest rates rose as high as 52 percent, depending on the loan cycle and repayment record, as a result of Zimbabwe's high rates of inflation.

\section{Characteristics of the Survey Sample}

Most survey respondents were women, since Zambuko loans primarily to women. In 1999, the respondents on average were 41 years old, with eight years of education. The majority were married, and 16 percent were widowed. Two-thirds of the respondents' households were poor, measured by global standards for determining per capita and daily income, taking into account purchase power parity. 
In 1997, 60 percent of the client respondents were on their first loan. After completion of that loan, approximately half of the 1997 clients took an additional loan. The analysis of the client respondents included both those who took an additional loan and those who had left the program. The average sum of all loans taken by the HIV-affected clients $(Z \$ 5,821)$ did not differ significantly from that of the other clients $(Z \$ 6,435)$.

\section{Key Findings}

\section{Forty percent of microentrepreneurs' households may be affected by HIV/AIDS.}

In 1999, 40 percent of both client and non-client households were possibly affected by HIV/AIDS, according to one or more of the study's proxy indicators. Between 1997 and 1999, half of the affected households had an adult member ( 20 years or older) who was seriously ill, and 34 percent had experienced the death of an adult member. Also, nearly one-third of the households had absorbed a new member since 1997. These new members was taken in due to illness or death in their previous households or because they were ill. At the time of the 1999 interview, one-fifth of the households had a member who was chronically ill during the past six months.

\section{HIV/AIDS adversely affects the financial status of microentrepreneurs' households.}

When the affected households were compared to non-affected households, these differences were apparent in 1999:

- The proportion of household members who were not economically active was greater in HIVaffected households (40 percent vs. 32 percent; $p<.01$ ).

- HIV-affected households (18 percent) were less likely than others (9 percent) to seek medical treatment when needed due to a lack of funds $(\mathrm{p}<.01)$.

- The monthly income for HIV-affected households was lower $(Z \$ 3,344$ vs. Z\$4,142; $<<.05)$.

The lower monthly income among HIV-affected households appears to reflect a smaller amount earned from the household's enterprises. The monthly net revenue from the household's enterprises was $\$ 521$ less for the HIV-affected households $(p<.05)$, when matching households to control for differences in 1997 in poverty status, economic dependency ratio, whether the household had been affected by serious illness or death between 1995 and 1997, and for level of monthly net revenue from household enterprises.

The findings suggest that chronic illness and death influence the amount of income the household earns from its enterprises, which in turn affects their overall monthly income level. The results imply that less attention is devoted to the household's enterprises when the owner and other households members have to address illness or death in the household. 


\section{Hgrizons}

\section{By 1999, HIV-affected clients had greater financial constraints than HIV-affected non-clients.}

Affected client households had more members and a higher ratio of members who were economically inactive. More affected clients (16 percent) than affected non-clients ( 9 percent) had become widowed since 1997, and there was greater loss of wages as a source of income among the affected clients. Possibly related to these other factors, a lack of funds caused more households of affected clients ( 22 percent) than affected non-clients (13 percent) not to seek medical services when needed during the six months prior to the 1999 interview.

\section{Participation in a microfinance program can lead to income smoothing and better financial management.}

The results of the impact analysis that controlled for selected initial differences suggest that participation in Zambuko's program had a positive effect on the HIV-affected client households. Given two households with the same poverty level, the same number of income sources, the same economic dependency ratio, and same status related to illness or death in 1997, the household with a Zambuko client had a significantly higher number of income sources than the affected non-client household in 1999. This impact result indicates that credit had permitted the client households to pursue an income diversification strategy to smooth the flow of household income, since enterprise earnings normally vary from month to month.

Participation in Zambuko's program also positively influenced the savings patterns of the clients from affected client households. Compared to affected non-clients, they tended to save in more ways, which is important since each savings mode usually has a different intended use, and a greater proportion had an individual savings account with a formal institution. These results are probably attributable to the financial management skills acquired through the training clients received and the discipline acquired through meeting loan repayment schedules.

\section{Zimbabwe's economic situation contributed more to repayment problems than illness and death.}

In the focus group discussions, both Zambuko officers and clients felt that the deteriorating economic situation in the country was more of a factor than illness and death in contributing to loan repayment problems in 2000. Also that year, the tense political situation had a negative impact on clients who had customers on commercial farms and in other rural areas. The general opinion was that if economic conditions had been better, households would have been better able to cope with the economic impact of illness and death. Nonetheless, clients and Zambuko officers who participated in the focus groups also felt that loans are a burden when the client is seriously ill or has to care for a person who is chronically ill. 


\section{Instituting mandatory insurance fees and providing HIV/AIDS information to clients are among Zambuko's responses.}

Zambuko does not have a basis for estimating the impact of HIV/AIDS on its program and clients, but it has taken measures to reduce risks to its financial portfolio that are associated with HIV/AIDS and other factors. In January 2001, Zambuko instituted a mandatory insurance fee of 1 percent to cover the outstanding loans of borrowers who die. Other policy changes that have helped Zambuko manage risks include a mandatory savings requirement and strict enforcement of group co-guarantees of loan installments.

Other proactive measures have been taken by Zambuko's Trust Bank Program, which targets the poor. HIV/AIDS specialists have attended meetings of Trust Bank clients to discuss ways to care for an HIV-infected person. Other experts talked about legal issues facing women, such as dealing with relatives' claims on a deceased husband's property.

\section{Proposals to help MFIs respond to client needs include training, new loan products, and networking.}

A number of suggestions were made in the focus groups with clients and Zambuko staff. These include:

- Provide smaller, shorter-term loans (e.g., six months) to reduce the risk of loan defaults since the economic situation and prevalence of HIV/AIDS make it difficult to predict if individuals can meet their loan obligations over a nine- to twelve-month period.

- Educate clients about HIV/AIDS-related issues.

- Train loan officers in communications skills to better enable them to respond to the HIV/AIDSrelated situations they encounter.

- Encourage clients to teach teenage sons and daughters how to manage their enterprises, so that the child could operate the business if the owner became ill or died, or had to focus on caring for a sick person.

Representatives of MFIs, HIV/AIDS service organizations, and donors participating in the forum stated that the forum should be regarded as the launching of networking and collaboration between MFIs and HIV/AIDS service organizations. They suggested a role for a permanent forum and identified a facilitator. The participants also suggested a number of ways that MFIs might better address the impact of HIV/AIDS on their institutions and clients. For instance, they suggested that MFIs work together to combat the denial of HIV/AIDS in Zimbabwe. There was general agreement that MFIs should develop new products and take actions to ensure that their clients are better educated about HIV/AIDS-related topics. The education might be provided by the MFI or by establishing linkages with an HIV/AIDS service organization. 


\section{Hgrizons}

\section{Conclusions}

This study was one of the first of its kind to explore the relationships between participation in a microfinance program by microentrepreneurs with established businesses and the household's ability to mitigate the economic impacts of chronic illness and death. The findings indicate several small yet important ways that MFI programs help microentreprenuers and their families respond to these impacts, advantages that are associated with access to credit and business management training.

The following recommendations emerged from the study and have policy, program, and research implications for MFIs, AIDS service organizations, donors, and governments.

\section{Recommendations}

- A set of tools should be developed and tested that would permit MFIs and other programs to better estimate HIV/AIDS-affectedness among their clients and target groups.

- Despite the growing financial needs of households coping with chronic illness and death, MFIs operating in countries with high inflation must keep their interest rates and fees in line with inflation or risk eroding their capital base.

- MFIs need to consider HIV/AIDS from the standpoint of the organization, its outreach, and its client base. They should focus on ways to manage risks (e.g., mandatory insurance fees) and experiment with measures and services to ameliorate the impact of HIV/AIDS on their target populations. Operations research should be undertaken to determine the feasibility of new programs, services, and products.

- The legal framework for non-banking microcredit organizations should be changed to enable them to collect voluntary deposits, such as savings and funeral funds.

- MFI loan officers should be trained in communication techniques to enhance their ability to respond to the HIV/AIDS situations they encounter. Also, they should be given basic counseling skills or be informed about existing services to which they can refer individuals.

- A similar study ought to be undertaken in a more stable economic environment. The economic impacts of HIV/AIDS on households and of microfinance on affected clients may thus be more apparent, since these will not be co-mingled with negative macroeconomic factors. 


\section{Introduction}

HIV/AIDS is a major crisis in sub-Saharan Africa, adversely affecting millions of households. In recent years, microfinance has been proposed as a strategy to enable households to respond to the negative economic impacts of HIV/AIDS. This attention to the potential role of microfinance builds on an earlier focus on microfinance as an approach to improving the lives of the poor. That focus was accompanied by attention to the sustainability of microfinance services provided by nongovernmental organizations, through charging commercial rates of interest and using sound business practices. This type of microfinance institution (MFI) usually offers small-sized loans, often combined with savings services, to microentrepreneurs. MFIs may also offer business management training, health and nutrition education, and other types of services.

Recent studies of microfinance programs have documented that most of the clients hover around the poverty line, above and below it. MFIs provide a valuable source of credit for these households. Some programs reach the very poor, but normally they are not the main group accessing the services. Recent impact studies have documented the positive impact of MFI programs, but the impacts have often been more modest in scale than often assumed (Sebstad and Cohen 2000; Barnes 2001; Dunn and Arbuckle 2001; Chen and Snodgrass 2001).

This study responds to the need for empirical data to better understand the effect of HIV/AIDS on households and the role of microfinance in enabling microentrepreneurs' households to respond to the negative economic impacts of HIV/AIDS. The study also discusses policies and activities to mitigate the vulnerability of MFIs and their clients to the economic impacts of HIV/AIDS. A number of other issues related to the potential of MFIs to mitigate the impact of HIV/AIDS are beyond the scope of this study, such as training individuals to become microentrepreneurs, and savings services for the poor.

\section{Objective}

The main objective of this exploratory study is to better understand the relationship between microfinance programs and microentrepreneurs' households coping with HIV/AIDS. The following key questions guided the study.

- To what extent are microentrepreneurs' households affected by HIV/AIDS?

- What economic effect does HIV/AIDS have on microentrepreneurs and their households?

- Among those affected by HIV/AIDS, do clients of MFI programs differ from non-client microentrepreneurs?

- Does participation in a MFI program mitigate the economic impact of HIV/AIDS on households?

- How have chronic illness and death affected the operations of MFIs and participation in their programs? 


\section{Hgrizons}

- What might MFIs do to lessen the impact of HIV/AIDS on their clientele and on their organizations?

The study is exploratory since proxy indicators were used to identify HIV-affected households. No attempt was made to verify the reasons for illness and death identified by the proxy indicators, because Zimbabweans normally do not admit to having HIV/AIDS-infected household members and are silent if they are themselves HIV-positive. Moreover, most Zimbabweans are reluctant about learning their serostatus. Also, the study is exploratory since there is limited evidence to date to suggest the best proxy indicators of HIV/AIDS infection and persons affected by HIV/AIDS.

\section{Scope of the Study}

The study builds upon the assessment of Zambuko Trust that was undertaken by USAID's Assessing the Impact of Microenterprise Services (AIMS) Project. The AIMS assessment included a two-stage survey of Zambuko clients and non-client microentrepreneurs conducted in 1997 and 1999. The AIMS report centers on whom Zambuko reaches, the role of Zambuko loans in the household economy, and the impact of participation in Zambuko's program on continuing and departing clients (Appendix A contains a summary of Barnes 2001).

In this study, we were first interested in exploring the extent to which HIV/AIDS was affecting the households that participated in the survey. Respondent households were classified as possibly affected by HIV/AIDS during the 1997-1999 period if they met one of the following criteria:

- A member chronically ill and unable to work in the six months prior to the 1999 interview, or

- Absorbed one or more of the following into their household since the 1997 interview and the person remained for more than six months: a sick person, an adult due to death in prior household, or a child due to one or both parents having been sick or died, or

- Serious illness of respondent, spouse or household member 20 years old or older, which caused a financial crisis since the 1997 interview, or

- Death of spouse or household member 20 years old or older, which caused a financial crisis since the 1997 interview.

Then we sought to determine whether there were significant differences between the households that were possibly affected by HIV/AIDS and those that were not. The results suggest the impact of HIV/AIDS on affected households.

Second, we were interested in whether participation in a microfinance program helps those who become affected by HIV/AIDS. To explore this question, we divided the respondent microentrepreneurs from the survey into four groups, as indicated below.

Possibly HIV-affected clients

Possibly HIV-affected non-clients
Other clients

Other non-clients 
Thereafter, we looked at differences and similarities in demographic characteristics of the households in 1997 and 1999, and changes between the two years. Then we focused on the affected clients and affected non-clients. After identifying the key differences in the basic characteristics of their households, we analyzed the impact of microfinance on affected clients and their households and enterprises. ${ }^{2}$

Third, we wanted to better understand the extent to which chronic illness and death had affected the operations of the microfinance institution, and measures taken by Zambuko to lessen the potential negative effects of HIV/AIDS on its operations. Also, we wanted to learn staff perspectives on issues related to HIV/AIDS. Fourth, we sought to understand dynamics within loan guarantee groups related to HIV/AIDS, whether participation in a microfinance program was influenced by chronic illness and death, and suggestions on ways organizations might better assist microentrepreneurs who are affected by HIV/AIDS. Finally, we wanted to encourage linkages among MFIs and HIV/AIDS service organizations to address the situation in Zimbabwe.

\section{Key Contextual Factors}

The macroeconomic and social environment influences circumstances, options, and choices of households and owners of microenterprises. The larger environment also influences the operations of microfinance institutions.

Zimbabwe's annual inflation rate as measured by the Consumer Price Index (CPI) soared during the study period. In the 12 months after launch of the survey in September 1997, the CPI rose 32 percent. Between September 1998 and September 1999 inflation was 70 percent, and the following year it was 62 percent.

In 1998 an estimated 25 percent of Zimbabwe's working population were employed (including self-employed) in micro and small enterprises. Between 1991 and 1998 the number of microenterprises increased by 30 percent in the urban areas. Increases in the urban population, job retrenchment, and increasing consumer prices contributed to this growth rate. In 1998 approximately 45 percent of the enterprises were engaged in trade, which tends to have low entrance costs (McPherson 1998).

The negative influence of the macroeconomic environment has been exacerbated by the high incidence of HIV in Zimbabwe. In 1999 an estimated one-quarter of the Zimbabweans aged 15 to 49 were HIV-positive. Overall, an estimated 1.5 million adults and children were infected by the end of 1999 (UNAIDS and WHO 2000).

\footnotetext{
${ }^{2}$ The analysis also included the other clients and other non-clients, but only the results for the two affected groups are discussed in the text. Appendix $\mathrm{C}$ includes key findings on the four groups.
} 


\section{Hgrizons}

\section{Zambuko Trust}

The study centers on Zambuko Trust (Zambuko). It gives more loans to microentrepreneurs than any other organization in Zimbabwe. Begun in 1992, it had 24 branch offices by late 2000.

Zambuko covers all of the major urban centers as well as key secondary towns. Zambuko's mission is "to be a bridge between the marginalized, the unemployed and opportunities for enterprise and income generation." Its stated goal is to become a self-supportive and viable organization.

Zambuko, a partner in the Opportunity International Network, is a licensed moneylender registered in accordance with the provisions of the Money Lending and Rates of Interest Act, which regulates interest-bearing loans. Zambuko's legal status as a moneylender does not permit it to accept voluntary deposits and hence its scope of financial services is restricted.

Loans are its main product. Zambuko loans to (1) microentrepreneurs who join together in a group of five to six individuals to co-guarantee loans to its members, and (2) individual microentrepreneurs with an individual guarantor. Loans tend to be from nine to twelve months, with monthly loan installments. The credit is supplemented by two to four hours of training on business management during the initial orientation session, and informal business management advice from loan officers. Zambuko also has a Trust Bank product for the poor that requires potential borrowers to attend a one-hour training session for eight weeks prior to receipt of their loan. The training includes attention to good business management practices. Trust Bank loans are for groups of ten or more individuals who co-guarantee the loans to its members. Trust Bank loans are normally for six months with monthly installments. Irrespective of loan product, borrowers are required to pledge a non-essential asset as security.

Zambuko primarily loans to women. More than three-fourths of its clients are women. Approximately 45 percent of its clients are traders and 40 percent of its clients are engaged in manufacturing, such as knitting sweaters and sewing. The others are engaged in services, agriculture (livestock rearing and market gardens), and food preparation.

In 1997 the average loan was Z\$2,600 (equivalent to US\$218). In 2000 the average loan was $\mathrm{Z} \$ 10,200$ (equivalent to US\$185). The rise in the size of the loan in Zimbabwe dollars reflects the inflationary environment in the country. At the time of the 1997 survey, Zambuko charged a 32 percent annual interest rate. The following year the interest rate was increased to 35 percent. In 1999 the rate was 45 percent. In late 2000, the interest rates were between 48 and 52 percent, depending on the loan cycle and repayment record. New entrants were charged 52 percent, and those on their fifth or higher loan cycle who had a good payment record were charged 48 percent. 
Microfinance, Households, and HIVIAIDS

\section{Approach and Comparison Groups}

This section explains key terms, the study design, and statistical methods employed. It also provides information on the main comparison groups and key characteristics of the survey respondents. The latter includes data on the intensity of the client respondents' participation in Zambuko's program.

\section{Definitions of Key Terms}

A household is defined as one or more persons who (1) usually live and eat together, whether or not they are related by blood, marriage, or adoption, and (2) recognize each other as members of the same household. Using USAID's definition, microenterprises are very small, informally organized business activities (not including crop production) undertaken by low-income people. Microenterprises are further defined as having ten or fewer employees, including the owner operator and any paid or unpaid workers (USAID n.d.). Microentrepreneurs are the owneroperators of microenterprises. For the purposes of the study, no attempt was made a priori to determine if a Zambuko client met these criteria. Judging from the survey findings, all of them met the employment criteria and two-thirds were poor, measured in terms of daily per capita income.

\section{Mixed Methods ${ }^{3}$}

Quantitative and qualitative approaches were used to gather information. The AIMS assessment of Zambuko included a longitudinal study of a randomly selected sample of Zambuko clients from Harare, Chitungwiza, Bulawayo, and Mutare. ${ }^{4}$ It also covered a randomly selected group of nonclient microentrepreneurs from these areas. ${ }^{5}$ The initial round of the survey was undertaken between September and November 1997 (Barnes and Keogh 1999). The follow-up survey was carried out during the same months in 1999 , to control for seasonal variation.

The survey findings are complemented by information gathered in focus groups and key informant interviews in December 2000 and January 2001. Focus group discussions were held with a randomly selected sample of clients who participated in the survey and current clients in the four survey areas. In total, 140 microentrepreneurs participated in the sessions. Also, 33 loan officers and branch managers from the Bulawayo, Mutare, and Harare regions (the latter region includes

\footnotetext{
${ }^{3}$ Appendix B further describes the study design and methods.

${ }^{4}$ These urban areas contain the majority of Zambuko's clients.

${ }^{5}$ The non-client respondents were randomly selected using the following criteria: (1) had not received a loan for their enterprise from a formal institution, (2) were the sole or joint owner of a microenterprise that was at least six months old, and (3) did not work full time elsewhere. These criteria mirror the basic eligibility criteria used by Zambuko. Each non-client respondent was matched with a client respondent on the basis of gender, enterprise sector, and neighborhood.
} 


\section{Hgrizons}

Chitungwiza) participated in focus group discussions, and seven senior managers of Zambuko were interviewed.

Thirty-two persons from a range of organizations participated in a one-day forum in Harare held September 13, 2001. After the study's findings were presented, three groups containing a mix of persons from different types of organizations, discussed the implications of the findings in relation to what is currently being done and what else might be done. Later three groups-MFIs, HIV/AIDS service organizations, and donors - met to discuss what their "sector" might do. Highlights of the small group discussions were reported back to all participants.

\section{Statistical Methods}

The survey data were analyzed using two statistical methods that take into account the possibility that the comparison groups might have differed in 1997 in ways that may have affected the findings in 1999. First, the gain score analysis examines the change in performance from the initial survey to the follow-on survey. As such, it does not assume that the two groups were similar in 1997 on the variable analyzed.

Second, to identify the impact of HIV/AIDS on households and the impact of Zambuko on clients and their households, a special statistical approach was used. An analysis of covariance (ANCOVA) approach was used to control for differences between the comparison groups in 1997 on values for specific variables. The ANCOVA controlled for these variables: poverty level of the household, household economic dependency ratio, whether or not the household was affected by illness or death between 1995 and 1997, and the 1997 value for the variable analyzed. (See Appendix B for further information on the statistical methods used.)

The gain score analyses and ANCOVA analyses, as well as other tests used, involved statistical tests of significance on the differences found between the comparison groups. For the reader unfamiliar with statistical tests of significance, the test indicates the probability that the observed result is not just a chance coincidence. In this report, four levels of significance are used: $<.01,<$ $.05,<.10$, and $<.15$. A $<.05$ result signifies that there is a probability of between 1 and 5 in 100 that the apparent difference between the comparison groups would have occurred due to chance; it indicates that there is a positive correlation between the dependent variable (e.g., affected clients/affected non-clients) and the independent variable (e.g., number of income sources). The smaller the probability (e.g., $<.01$ ), the stronger the case that the difference is not due to chance. When the probability is $<.15$, the results are considered as marginally significant, but the review of the statistical data suggested that the difference is meaningful.

\section{Comparison Groups}

As mentioned above, the survey data were analyzed by using two comparison groups: possibly $H I V$-affected microentrepreneurs and other microentrepreneurs. Then data were analyzed across four comparison groups: possibly HIV-affected clients, possibly HIV-affected non-clients, other 
clients, and other non-clients. For ease of reading, the possibly HIV-affected respondents are often referred to as $H I V$-affected or affected. It is important for the reader to remember that participation in Zambuko's program preceded the events that led to classification of the borrowers by whether or not their household had been possibly affected by HIV/AIDS.

The classification of clients and non-clients is based on the status of the respondent in $1997 .{ }^{6}$ The analyses are based on a sample of 579 respondents: 338 clients and 241 non-clients. In 1999, in 36 instances a knowledgeable household member provided responses, since the 1997 respondent was not available during the study period. These substitute respondents were excluded from the analysis of respondent characteristics and the impact analysis on the individual borrower.

\section{Characteristics of Survey Respondents}

Most of the survey respondents were women, since Zambuko loans primarily to women. In 1999 the respondents tended to be 41 years old, with eight years of education (Table 1). The majority were married, and 16 percent were widowed. More than one-fifth of the affected respondents were widowed. Widowhood among the other respondents reflects that they were widowed in 1997 but had not experienced HIV-related events in their household since then.

Table 1 Sociodemographic characteristics of the respondents

\begin{tabular}{|c|c|c|c|c|c|}
\hline & \multicolumn{2}{|c|}{ HIV-affected } & \multicolumn{2}{|c|}{ Others } & \multirow{2}{*}{$\begin{array}{l}\text { Total } \\
\mathrm{n}=543\end{array}$} \\
\hline & $\begin{array}{l}\text { Clients } \\
n=124\end{array}$ & $\begin{array}{c}\text { Non- } \\
\text { clients } \\
n=88\end{array}$ & $\begin{array}{l}\text { Clients } \\
\mathrm{n}=194\end{array}$ & $\begin{array}{c}\text { Non- } \\
\text { clients } \\
\mathrm{n}=137\end{array}$ & \\
\hline$\%$ Female respondents & 87 & 85 & 85 & 85 & 85 \\
\hline $\begin{array}{l}\text { Average age of respondent, } \\
1999\end{array}$ & 42 & 40 & 41 & 40 & 41 \\
\hline $\begin{array}{l}\text { Average educational level of } \\
\text { respondent }^{\mathrm{a}}\end{array}$ & 8 & 7 & 8 & 7 & 8 \\
\hline \multicolumn{6}{|l|}{ Marital status, 1999} \\
\hline Married & 63 & 67 & 75 & 77 & 71 \\
\hline Widowed & 25 & 22 & 11 & 10 & 16 \\
\hline Single/divorced/separated & 12 & 11 & 14 & 13 & 13 \\
\hline
\end{tabular}

\footnotetext{
${ }^{6}$ The non-clients who had become Zambuko clients since the 1997 interview and the AIMS case study respondents were excluded from the database, resulting in a sample of 579 respondents.
} 


\section{Hgrizons}

\section{Intensity of Participation in Zambuko's Program}

In 1997, approximately 60 percent of the client respondents were on their first loan, while the others were repeat borrowers. After completion of the 1997 loan, 42 percent of the HIV-affected client respondents and 48 percent of the other clients continued to participate in Zambuko's program, taking one or more loans between 1997 and late 1999. The sum of all loans taken did not differ significantly between the affected clients and the other clients (Table 2). ${ }^{7}$ In 1997 the average size of the loan taken by client respondents was equivalent to 23 percent of the clients' monthly net revenue in the matched enterprise (i.e., the enterprise for which the loan had been taken), and was equivalent to 12 percent of the monthly household income. This suggests that the loan size was relatively small within the household economy, but significant in terms of net revenue of the matched enterprise. Beyond Zambuko, respondents had limited access to formal and informal sources of credit for their enterprises and households (Barnes 2001).

Table 2 Participation in Zambuko's program by affectedness status

\begin{tabular}{lcc}
\hline & HIV-affected clients & Other clients \\
\hline Participation indicators & $\mathrm{n}=134$ & $\mathrm{n}=204$ \\
$\%$ new clients in 1997 & 60 & 61 \\
$\%$ continued since 1997 & 42 & 48 \\
Average number loans & 2.1 & 2.2 \\
Average sum all loans (Z\$) & 5,821 & 6,435 \\
Continuing clients and amount borrowed & $\mathrm{n}=56$ & $\mathrm{n}=99$ \\
since 1997 & & 6,870 \\
Average sum since 1997 (Z\$) & 6,416 &
\end{tabular}

\footnotetext{
${ }^{7}$ One U.S. dollar was equal to Z\$11.9 in September 1997 and to Z\$38.1 in September 1999.
} 


\section{Key Findings}

\section{To What Extent Does HIV/AIDS Affect Microentrepreneurs and Their Households?}

Forty percent of the client households and 39 percent of the non-client households were possibly $H I V$-affected in 1999. Serious illness of spouse, self, or other household member 20 years old or older was the most common indicator of being HIV-affected (Table 3). There was a relatively high rate of death of a spouse or another household member 20 years or older among the affected households. Clearly 34 percent of the affected client households and 24 percent of the affected nonclient households had experienced the death of an adult member in the past two years. One-fifth of the households reported a chronically ill member, and slightly more than one-quarter had absorbed a person into their household who was ill or had experienced chronic illness or death in a previous household. ${ }^{8}$

\section{Table 3 Distribution of illness and death among HIV-affected clients and} non-clients, 1999 (percentage)

\begin{tabular}{lccc}
\hline & $\begin{array}{c}\text { Clients } \\
\mathbf{n = 1 3 4}\end{array}$ & $\begin{array}{c}\text { Non-clients } \\
\mathbf{n = 9 4}\end{array}$ & $\begin{array}{c}\text { Total } \\
\mathbf{n = 2 2 8}\end{array}$ \\
\hline $\begin{array}{l}\text { Serious illness of respondent, spouse, or household } \\
\text { member }>20 \text { years the last 2 years }\end{array}$ & 47 & 55 & 50 \\
$\begin{array}{l}\text { Death of spouse or other member }>20 \text { years the } \\
\quad \text { last 2 years }\end{array}$ & 34 & 24 & 30 \\
$\begin{array}{l}\text { Absorbed new household member due to illness or } \\
\text { death the last 2 years }\end{array}$ & 30 & 27 & 21 \\
Chronically ill household member, the last 6 months & 22 & 19 & 29
\end{tabular}

\footnotetext{
${ }^{8}$ The cases of chronically ill persons are also captured in the more general question on serious illnesses. These cases suggest an advanced stage of infection.
} 


\section{Hgrizons}

An analysis was conducted to determine if there is a relationship between a household's poverty level and the likelihood that it would be affected by HIV. Poverty was defined in terms of per capita daily income, taking into account key expenditures and assets. Households were then categorized as extremely poor, moderately poor, and non-poor. ${ }^{9}$ The results of the analysis do not indicate that the 1997 poverty level of the household was related to the household experiencing events associated with HIV-affectedness between 1997 and 1999.

\section{What Is the Economic Effect of HIV/AIDS on Households?}

HIV-affectedness was found to be negatively associated with the proportion of the household's members who were economically active, the role of enterprise income in the household's economic portfolio, and the ability to seek medical treatment. Affectedness led to a rise in the proportion of the household's members who are not economically active (Table 4). In 1999, the HIV-affected households had a significantly higher economic dependency ratio (40 percent) than the other households (32 percent). This reflected a significantly greater increase in the economic dependency ratio of affected households than others since 1997.

Between 1997 and 1999, the ratio of enterprise income to total household income decreased more for the affected households than the other households, suggesting that illness and death influenced the decline. Moreover, affected households (18 percent) were more likely than other households (9 percent) to have not sought medical treatment when needed due to a lack of funds.

When controlling for specific differences between respondents in 1997, HIV-affectedness appears to have specific negative economic impacts on households (Table 5). The monthly household income level for HIV-affected households was estimated to be Z\$525 less than for other households. Also, the monthly net revenue in the household's enterprises was Z\$521 less a month for the affected households compared to the other households. The findings suggest that illness and death influence the amount of income the household earns from its enterprises, which in turn affects their overall monthly income level. The results imply that less attention is devoted to the household's enterprises when the owner and other household members have to address chronic illness or death in the household. ${ }^{10}$

\footnotetext{
${ }^{9}$ Poverty was defined using global standards related to purchase power parity to determine per capita per day income. The extremely poor are those households under the US\$1 a day per capita poverty line, the moderately poor are between US\$1 and $\$ 2$ a day per capita poverty lines, and non-poor are above US\$2 a day per capita poverty line, taking into account key expenditures and assets (see Barnes 2001).

${ }^{10}$ The findings for 1997 and 1999 are given for these impact variables and other variables in tables 11 and 12 in Appendix C.
} 
Table 4 Key differences between HIV-affected households and other households (percentage distribution)

\begin{tabular}{|c|c|c|c|}
\hline & Affected & Other & $\begin{array}{c}\text { Statistical } \\
\text { significance }\end{array}$ \\
\hline Economic dependency ratio & $n=228$ & $n=351$ & \\
\hline 1997 & 31 & 29 & \\
\hline 1999 & 40 & 32 & $<.01$ \\
\hline Gain score change & 9.6 & 2.8 & $<.01$ \\
\hline $\begin{array}{l}\text { Ratio of enterprise income to total household } \\
\text { income }\end{array}$ & $n=221$ & $n=282$ & \\
\hline 1997 & 75 & 66 & $<.01$ \\
\hline 1999 & 55 & 57 & \\
\hline Gain score change & -20 & -9 & $<.01$ \\
\hline $\begin{array}{l}\text { Did not seek medical treatment when needed } \\
\text { in past } 6 \text { months due to lack of funds (1999) }\end{array}$ & $n=228$ & $n=351$ & \\
\hline Yes, unable to seek treatment & 18 & 9 & $<.01$ \\
\hline
\end{tabular}

On a number of other economic indicators, the impact analyses suggest that HIV-affected households were similar to the other households; thus, it appears that affected households were no worse off than the other households when controlling for specific, initial differences. For example, no statistically significant differences were found between affected households and other households on the following: per capita monthly income, frequency of consumption of specific nutritious food items, proportion of the household's boys and girls ages 6 to 16 in school, the proportion of the household's boys and girls ages 6 to 21 in school, and person-hours worked in household enterprises. 
Table 5 Impacts of HIV-affectedness suggested by the ANCOVA analyses

Findings: 1999 compared to $1997^{*}$

Statistical significance

At the household level, affected households compared to other households had:

- $\quad$ Lower level of monthly household income $(Z \$ 535)$

At the enterprise level, affected household compared to other households had:

- $\quad$ Lower level of monthly net revenue in matched enterprise $(Z \$ 628)$

- Lower level of monthly net revenue from all the household's enterprises (Z\$521)

- Fewer person hours worked last week in matched enterprises (13 person hours)

\section{At the individual level, affected respondents compared to other} respondents had:

- Greater proportion with an individual savings account with a formal institution (6 percent)

\footnotetext{
* The analysis took into account specific initial differences in 1997, including household poverty level, household economic dependency ratio, and whether or not the household had a crisis due to illness or death of a member between 1995 and 1997. The 1999 dollar values have been adjusted to 1997 constant values to take inflation into account. Matched enterprise refers to the enterprise for which the client had taken their 1997 loan, and the non-client selection criteria included having an enterprise in the same sector as the client.
}

\section{Do HIV-affected Clients Differ From HIV-affected Non-clients?}

\section{Changes in income levels}

Between 1997 and 1999, the net revenue (profit) from the matched enterprise (the enterprise for which the clients had received their 1997 loans and against which the non-clients were matched) of both the HIV-affected clients and non-clients decreased. Since the decline may have been attributable to the microentrepreneurs focusing more on another household enterprise, an analysis was conducted on the monthly net revenue of all the household's enterprises (Table 6). The results also reveal a decline among affected clients (Z\$456) and affected non-clients (Z\$192), whereas there were gains among non-affected microentrepreneurs. The decline in profits from enterprises belonging to both affected household groups suggest that the affected households had spent less attention on positioning themselves in a competitive and declining market. 


\author{
Table 6 Average total net revenue from household enterprises last \\ month, 1997 and 1999 (Zimbabwe dollars in 1997 constant values)* \\ HIV-affected

\begin{tabular}{lcc} 
& $\begin{array}{c}\text { Clients } \\
\mathbf{n}=\mathbf{1 0 4}\end{array}$ & $\begin{array}{c}\text { Non-clients } \\
\mathbf{n}=\mathbf{7 3}\end{array}$ \\
\hline $1997^{\mathrm{a}}$ & 2,672 & 1,822 \\
$1999^{\mathrm{b}}$ & 2,215 & 1,630 \\
Gain score & -456 & -192
\end{tabular} \\ *Analyzes those with enterprises in 1999 and with complete information for both years. \\ Outliers (values more than three standard deviations from the mean) were removed. \\ a Significant difference at $p \leq .05$ ). \\ ${ }^{\mathrm{b}}$ Significant difference at $\mathrm{p} \leq .10$ ).
}

Nevertheless, between 1997 and 1999, the households of affected clients were able to increase their per capita monthly income by Z $\$ 21$, whereas it decreased among the affected non-client households. ${ }^{11}$ This result signifies that the average per capita monthly income for affected clients had kept pace with inflation. The findings on per capita monthly income and household enterprise income for the affected clients imply that they had become more reliant on non-enterprise income. $^{12}$

\title{
Key characteristics of affected clients and affected non-clients
}

In 1999 the households of affected clients differed from affected non-clients households on a number of factors. Affected client households had more members and a higher economic dependency ratio. Slightly more affected clients than affected non-clients had become widowed since 1997. Also, the loss of wages as a source of income was more pronounced among the affected clients compared to the affected non-clients. Possibly related to these other factors, a lack of funds caused more households of affected clients ( 22 percent) than affected non-clients (13 percent) to not seek medical services when needed during the six months prior to the 1999 interview.

\footnotetext{
${ }^{11}$ All of the 1999 income and net revenue data were adjusted to 1997 constant values to take into account inflation. See tables 15-20 in Appendix C.

${ }^{12}$ See tables 17-22 in Appendix C.
} 
Table 7 Key differences between HIV-affected clients and HIV-affected non-clients

HIV-affected

Clients Non-clients

\begin{tabular}{|c|c|c|}
\hline \multicolumn{3}{|l|}{ Average household size } \\
\hline $1997^{\mathrm{a}}$ & 5.9 & 5.2 \\
\hline $1999^{a}$ & 6.2 & 5.4 \\
\hline \multicolumn{3}{|l|}{ Widowhood } \\
\hline \% who became widowed since 1997 & 16 & 9 \\
\hline \multicolumn{3}{|l|}{ Economic dependency ratio } \\
\hline 1997 & 31 & 30 \\
\hline $1999^{b}$ & 43 & 37 \\
\hline Gain score change & 11 & 7 \\
\hline \multicolumn{3}{|c|}{$\begin{array}{l}\text { Did not seek medical treatment when needed in } \\
\text { past } 6 \text { months due to lack of funds (1999) }\end{array}$} \\
\hline Yes, unable to seek medical assistance ${ }^{b}$ & 22 & 13 \\
\hline \multicolumn{3}{|l|}{ Households with a wage earner } \\
\hline None, 1997 and 1999 & 30 & 39 \\
\hline Yes, 1997 and 1999 & 40 & 34 \\
\hline Yes 1997, no 1999 & 21 & 13 \\
\hline Yes 1999, no 1997 & 10 & 14 \\
\hline
\end{tabular}

\section{Does Participation in an MFI Program Mitigate the Economic Impact of HIV/AIDS on Households?}

\section{Impact of microfinance on affected clients}

The impact analyses suggest a limited but important, number of ways that participation in Zambuko's program had a positive impact on affected clients and their households. The ANCOVA results suggest that affected client households had more sources of income than the affected non- 
client households, indicating that these clients had pursued an income smoothing strategy (Table 8). Also, the affected client households, compared to the affected non-client households, had a higher proportion of the household's boys ages 6 to 16 enrolled in school, indicating investment in the human resources of its members.

\section{Table 8 Impacts of microfinance on affected clients suggested by the ANCOVA} analyses of the survey data

Findings (1999 compared to 1997) ${ }^{\mathrm{a}} \quad \begin{gathered}\text { Statistical } \\ \text { significance }\end{gathered}$

At the household level, HIV-affected clients compared to HIV-affected non-clients had:

- Greater number of household income sources $(.23)<.01$

- Higher proportion of the household's boys ages 6-16 in school (5\%) <.10

At the enterprise level, HIV-affected clients compared to HIV-affected non-clients had:

- Fewer total person hours a week in their matched enterprise $(13<.15$ person hours)

- Worked fewer hours the previous week in household enterprises $(8<.05$ hours)

- Greater proportion who insist on a deposit when extending credit to $<.10$ customers $(13 \%)$

\section{At the individual level, HIV-affected clients compared to HIV-affected} non-clients had:

- Greater proportion with an individual savings account with a formal $<.01$ institution (16\%)

- $\quad$ Saved in more ways (.43)

$<.01$

${ }^{a}$ These estimates are derived from the impact analysis that was conducted on the four comparison groups. The analysis took into account specific initial differences in 1997, including household poverty level, household economic dependency ratio, and whether or not the household had a crisis due to illness or death of a member between 1995 and 1997.

In addition, Zambuko's program appears to have had an impact on the way affected clients managed their finances. In 1999, 13 percent more of the affected clients than the affected nonclients insisted on a deposit when they extended credit to their matched enterprise customers. Also, 16 percent more affected clients than affected non-clients had an individual savings account with a 


\section{Hgrizons}

formal institution. In addition, the average number of ways the respondent saved was higher for the affected clients than affected non-clients. These differences imply that Zambuko's business management training has a positive impact on the way affected clients manage their money. ${ }^{13}$

The ANCOVA results also suggest a negative relationship between participation in Zambuko's program and employment in the household's enterprises. ${ }^{14}$ In 1999, the number of person hours worked in the matched enterprise the week prior to the interview was 13 hours less for the affected clients than the affected non-clients. The reason might be associated with a decline in the importance of the matched enterprise to the household economy. Nevertheless, affected client respondents worked eight hours less the week prior to the interview in all household enterprises than did the affected non-clients. Since affected client households had a higher economic dependency ratio, the reason may be associated with fulfilling other responsibilities.

\section{How Have Chronic Illness and Death Affected the Operation of MFIs and Participation in MFI Programs?}

\section{Impact of illness and death on Zambuko's program}

At the end of 2000, less than one half of one percent ( 0.32 percent) of Zambuko's outstanding loans were written off due to the death of clients. Beyond these data, Zambuko does not have a basis for estimating the impact of HIV/AIDS on its program and among its borrowers. Information from the AIMS survey and the focus group discussions imply that the client death rate between 1997 and 1999 was less than 1.5 percent per annum.

Zambuko has taken measures to reduce the impact of death on its financial portfolio. In January 2001, Zambuko instituted a mandatory insurance fee of one percent to cover the outstanding loan of borrowers who die. In addition, three other policies help to mitigate potential negative impacts on its portfolio: a mandatory savings requirement, loaning to persons who "look healthy," and strict enforcement of group co-guarantees of loan installments.

Pro-active measures have been taken by Zambuko's Trust Bank program to assist clients. Specialists attended meetings of Trust Bank clients and talked about how to care for an HIVinfected person and about legal issues facing women, such as dealing with relatives' claims on a deceased husband's property. Trust Bank clients have set up a client-managed voluntary funeral insurance scheme, but it appears that many clients have lost faith in the management of the scheme and Zambuko's legal status prevents it from operating the scheme.

\footnotetext{
${ }^{13}$ Table 22 in Appendix C contains the findings for 1997 and 1999, and changes between the two years on the impact variables.

${ }^{14}$ The analysis does not include the matched enterprises that had ceased operation since 1997.
} 


\section{Chronic illness and death and participation in Zambuko's program}

Clients may become ill or die during their loan cycle, or chronic illness or death of a household member or non-household member (such as an adult child or parents) may lead to difficulties in meeting loan installments. The focus group discussions provided examples on how these challenges were met and their influence on borrowers' dropping out of the microfinance program.

\section{Box 1: Examples of Difficulties Encountered When A Client Died}

A client with an individual loan of $Z \$ 12,000$ died, and then her husband died. As a result, her son took over responsibility for repayment of the loan, but when relocating to the rural areas he had a car accident and all of his property in the vehicle was destroyed. The son pays installments on the outstanding loan, although this is very difficult for him to manage.

A member of a loan co-guarantee group died only three days after receipt of her loan. The loan funds were still in her bank account. Neighbors informed the husband and, following their advice, he withdrew the money and ignored the deceased wife's debt. Despite appeals to the husband and mother-in-law, the group members ended up repaying the loan of their deceased member.

Prior to the recent enactment of a one percent fee for insurance that will pay off the loan if a borrower dies, loan groups or individual guarantors were responsible for payment if the deceased person's relatives did not repay the loan. When a group member is unable to make her monthly loan installment, other members of the group normally pay for her, but expect to be repaid. For example, a focus group participant explained that her group paid the loan installments of a member whose husband was in the hospital, and later the woman reimbursed them. The $Z \$ 1,000$ the group gave the woman when she ran out of money for bus trips to the hospital did not have to be paid back because it was given as an expression of support.

If a member has had difficulty making timely payments due to illness or death, Trust Bank groups tend to encourage the member to wait a while before taking another loan. In comparison, other loan guarantee groups normally

\section{Box 2: Caring for the Chronically III and Departing the MFI Program}

An elderly Bulawayo microentrepreneur stopped taking loans from Zambuko because she relocated to a rural area to care for her unmarried son, who was ill with tuberculosis. When the son died, she moved to Masvingo to care for an ill son-in-law. Spending time caring for the sick meant that her business activities were disrupted, so she was unable to continue in Zambuko's program.

allow the member to remain in their group for the next loan cycle, but may encourage the person to take a smaller loan. As one client explained, "If a member shows appreciation and commitment to 


\section{Hgrizons}

pay back members who bailed her out, we let her stay in the group for the next loan cycle." If, however, the individual had been "troublesome" before illness and death had led to repayment difficulties, the group normally does not allow the person to remain a member for the next loan cycle.

The findings on the survey respondents, like the results of the focus group discussions with clients, indicate that affectedness does not influence whether or not a microentrepreneur remains in the program. However, the survey results did reveal that a higher proportion of clients who had left the program after their 1997 loan, compared to those who took one or more loans after 1997, had a chronically ill household member in 1999. This finding suggests that illness over an extended period is likely to lead to individuals dropping out of a microfinance program. Clients and Zambuko officers in the focus groups echoed that loans are a burden when the borrower is coping with chronic illness, that is, when the client is seriously ill or has to care for a sick person.

Reasons other than chronic illness and death also cause individuals to drop out of Zambuko's program. Microentrepreneurs in the focus group sessions cited reasons why individuals left their loan groups and former clients explained why they had left. The latter regarded themselves as having "waited a time" before getting another loan, not as former clients. The reasons given for leaving the program include losing a market due to disturbances on commercial farms, relocation to another area, achievement of objective, and loan size too small.

In the focus group discussions, both Zambuko officers and clients felt that the economic situation in the country was more of a factor than illness and death in contributing to loan repayment problems in 2000. Also that year, the political situation had a negative impact on a sub-group of clients who were selling on commercial farms and in other rural areas. The general opinion was that if economic conditions were better, households would be better able to cope with the economic impact of chronic illness and death.

\section{What Measures Might Be Taken to Mitigate the Potential Negative Impact of HIV/AIDS on Microentrepreneurs and MFIs?}

The former and current clients and the loan officers and their branch managers who participated in the focus group discussions had a number of suggestions on interventions to address the impact of HIV/AIDS on microentrepreneurs' households and on microfinance programs. While the 
suggestions of the microentrepreneurs focused on MFIs, some of the suggestions may be applicable to other types of organizations. For example, informal funeral societies appear to be successfully operated and managed by churches and by cohesive community groups.

The suggestions are given below. Note that those marked with an $\mathrm{X}$ were mentioned by field officers, and those marked with a $\mathbb{C}$ were mentioned by clients.

- Microcredit targeted for enterprises should be extended to economically active microentrepreneurs, not to persons who are too sick to be economically active. C, X

- MFIs should defer payment of an installment to a later date and not charge interest and late payment fee; deferments need to be recorded. (C)

- MFIs should accept group loan installments when at least 80 percent of the members have paid, rather than demanding full payment or otherwise fining each member. (C)

- MFIs ought to charge a fee to ensure payment of outstanding loans of deceased borrowers. (C)

- MFI tracking systems for loan delinquencies should remove the names of deceased clients from delinquency lists in a timely manner, rather than at the end of the fiscal year. (X)

- MFIs ought to offer smaller loans with shorter repayment periods. (X)

- MFIs might have a special loan product that would target people caring for individuals with a terminal illness; these loans should be financed by a special fund established with donor monies to cover the loan and defaults. (X)

- MFIs might offer a well-managed, voluntary funeral policy to cover clients, their spouses, and unmarried children. (C)

- MFIs might offer restricted access savings accounts to enable individuals to save lump sums for emergencies and extraordinary expenditures. (C)

- MFIs should encourage clients to teach a teenage son or daughter to operate their business. (X)

- MFIs should provide awareness training workshops so clients would know where to go for HIV/AIDS-related assistance and basic information, including how HIV is spread and how to care for an HIV-infected person. (C)

- MFI officers need training in communication skills, particularly about the HIV/AIDS- related situations they encounter, and possibly counseling skills and knowledge about organizations to which they can refer clients. (X)

\section{What Actions Do Other Key Stakeholders Suggest to Address the Situation?}

Participants at the one-day forum on microfinance and HIV/AIDS in Zimbabwe mentioned a number of measures that might be undertaken to ameliorate the impact of HIV/AIDS on microfinance institutions and the households of microentrepreneurs. The reader may recall that the participants were from MFIs, HIV/AIDS organizations, and donor organizations. Time did not permit a thorough discussion of the feasibility and implications of each suggestion, and no attempt was made to reach a consensus. The main suggestions on which there seemed to be widespread agreement are summarized below. Appendix D presents a summary of the forum and additional suggestions. 


\section{Hgrizons}

- There is a need for more collaboration and information sharing between the different types of groups represented at the forum. A permanent consultative forum should be established to develop strategies to address the MFI-HIV/AIDS nexus and related issues and to follow up on progress made. There is also a need for a culture of learning and sharing and convergence of thinking about people and programs. This implies overcoming turf issues and competition for resources.

- Participants need to work together to combat the denial of HIV/AIDS in Zimbabwe.

- Participants need to better understand how microfinance program clients are coping with the impact of HIV/AIDS, who benefits from the services of HIV/AIDS support organizations and from MFI services, and what the program gaps are in reaching caregivers and at risk children, especially in rural areas. Innovative thinking is needed on addressing the gaps in existing programs and on program approaches.

- MFIs should develop new products and take action to ensure that their clients are better educated on HIV/AIDS-related topics. This education could be provided by the institution's staff or by an HIV/AIDS organization.

- MFIs should consider the household, not just individual microentrepreneurs, when giving loans. MFIs should recognize that money in the household is fungible and permit start-up activities and more than one household enterprise to be covered by a single loan. Upon the death of a client, another person from the household ought to be eligible to fill that deceased person's place in a loan group or with the loan institution, although the new member should receive the loan amount for first-time borrowers.

- MFI boards of directors and donors should reconsider their position on the timeframe for MFI financial sustainability, profitability, and productivity. They should think beyond these factors to consider the implications of HIV/AIDS on MFIs and microentrepreneurs. 
Microfinance, Households, and HIVIAIDS

\section{Implications of the Findings}

\section{Macroeconomic Conditions}

High rates of inflation are likely to place economic stresses on households and MFIs, limiting their ability to respond to the impacts of HIV/AIDS. If MFIs operating in inflationary environments do not increase their interest rates and fees to keep pace with inflation, they will erode their financial base. When government controls keep interest rates low, then special fees may be required. The macroeconomic conditions in Zimbabwe suggest that new microcredit programs and expansion of existing microcredit programs ought to proceed with caution or be put on hold until the economy is in a better state.

The results of Zimbabwe case study imply that development assistance organizations should focus more attention on assisting governments to strengthen policies that directly influence the ability of households to mitigate the negative economic impacts of HIV/AIDS.

\section{Legal Status of MFIs}

In a number of countries, the legal status of NGO microfinance institutions prevents them from taking voluntary deposits. That means they cannot offer voluntary savings services, operate funeral funds, and provide other services that entail collection of voluntary deposits. Laws governing institutions that can accept voluntary deposits have strict requirements to safeguard deposits. Since a number of HIV/AIDS mitigation activities involve voluntary deposits, NGO MFIs might need to work with the proper authorities to identify a more suitable legal status for their operations.

\section{Denial of HIV/AIDS}

Prevention and mitigation actions are hindered when there is widespread denial or silence about the incidence of HIV/AIDS in a country. MFI managers and boards of directors ought to join with those in other sectors to take an active role in opening discussion about HIV/AIDS in their countries. This implies that their organizations discuss the topic in a compassionate manner and devise strategies for dealing with affected clients and working with other stakeholder groups.

\section{Networks}

Networks of organizations within a sector and across sectors appear to be potentially powerful. Participants at the forum acknowledged that there were benefits to be gained from organizations sharing information and working cooperatively to address the impact of HIV/AIDS on MFIs and microentrepreneurs. If the network proves to provide a valued service, it is likely to serve as an example to others who would gain from joining together to discuss and act on ways to address the 


\section{Hgrizons}

impact of HIV/AIDS on their sector, geographic location, industry, and clients. For example, medium and large enterprises in a particular area might form a network to address HIV/AIDS in the workplace. Also, religious organizations might form a network to share information and strategies.

\section{Partnerships}

There is greater need for HIV/AIDS related education and information dissemination through partnerships between private and public sector organizations. For example, MFIs might form a partnership with public sector organizations to provide HIV/AIDS-related training to loan officers and clients.

\section{Estimating HIV-affectedness and Its Impact on Organizations}

Organizations normally do not have a basis for estimating the extent or ways their clients or target groups are affected by HIV/AIDS. Also, they often have no basis for estimating the impact of HIV/AIDS on their programs. In the short term, this implies two things. First, organizations should not feel compelled to provide estimates of the impact of HIV/AIDS on their programs and clients, unless they have a sound basis for making such estimates. Second, when organizations report reaching and having an impact on HIV/AIDS-affected persons, they ought to be able to explain how they derived their estimates. A set of tools should be developed and tested that would permit MFIs and other programs to better estimate affectedness among their clients and ways their programs are negatively affected by HIV/AIDS.

\section{Measures to Ameliorate the Impact of HIV/AIDS on MFIs}

The study points to the importance of mandatory insurance to cover the outstanding loans of deceased clients. Transparency and accountability ought to govern fees charged for loan insurance against death of the borrower. The income and payouts should be accounted for separately from other funds both to monitor the feasibility of the fee charged and to account for the use of the funds. Mandatory savings to cover defaults also appear to be a prudent policy.

In countries with high inflation and high HIV prevalence rates, it is difficult for loan officers and microentrepreneurs to predict what will happen over a nine- or twelve-month period. The findings suggest that there may be scope for loan products of a six-month or shorter duration.

In addition, there appears to be merit in adopting a new approach to loaning for microenterprise activities and vetting of loan applications. Currently organizations tend to loan to an individual for a specific enterprise rather than a set of household enterprises. MFIs might pilot test loans that would cover existing and new enterprises and assess loan applicants on the ability of the household to repay the loan, possibly requiring the contract to be co-signed by two adult household members. 
This could be combined with encouraging teenagers in the household to learn skills in managing and operating an enterprise (see below).

MFI managers and boards of directors need to consider HIV/AIDS both from the standpoint of the organization, given its outreach and its client base. This would imply that they actively participate in a forum or consultative group that brings together MFIs and HIV/AIDS service organizations. It also may require that MFI leaders and donors look beyond their current focus on financial sustainability to better understand the ways the epidemic affects sustainability and achievement of the MFI's stated mission. Financial sustainability is crucial but may take longer than anticipated to achieve, and complementary activities either by the MFI or through partnerships with other organizations may be warranted.

MFIs should focus more on delinquency management and how to manage risks, in recognition of the hardships faced by current and potential clients. They ought to be given the latitude to experiment with different strategies to determine their feasibility and impact.

\section{Increasing Households' Ability to Respond to Negative Economic Influences of HIV/AIDS-affectedness}

Microfinance appears to be a viable strategy for improving the ability of households to respond to the negative economic factors associated with HIV/AIDS-affectedness. It does this through presenting them with options for protecting themselves against these forces and improving financial management skills. When a household is in the midst of a crisis, however, credit appears to be a burden.

\section{Measures to Help HIV-affected Persons}

MFIs might experiment with criteria and procedures associated with granting a grace period when clients are faced with hardships due to chronic illness or death in their household. Also, they might experiment with criteria and procedures regulating payment of group loan installments. It may be feasible and prudent to accept 80 percent of the amount due, rather than require that 100 percent be paid each time.

MFI loan officers often encounter situations related to HIV/AIDS. They ought to be trained on how to communicate in these situations and the importance of verbal and non-verbal behaviors. They might also be provided with basic counseling skills and be updated on a regular basis on HIV/AIDS-related services so that they may inform their clients and others in need.

More needs to be done to educate people about HIV/AIDS and related topics. Since MFIs have links to communities, they might choose among the following options: set up a separate, 


\section{Hgrizons}

specialized unit; use their loan officers to provide education; or partner with another organization. ${ }^{15}$ Other organizations with networks within communities, such as churches and cooperatives, might also be enlisted to help with education following one of these approaches. Related to this, there is a need for short, simple, and clearly written educational materials on HIV/AIDS-related topics.

MFIs should encourage borrowers to train one of their teenage children to operate the enterprise. First, it would provide a fall-back position if the client becomes ill or has to take time away from the business due to caring for a sick person or attending funerals. Second, it would help install business knowledge and skills that could assist the child in future years, especially if economic hardships befall the household due to death of the adult income earners.

The findings suggest that there may be scope for other types of microfinance products. These include funeral insurance, limited access savings accounts, and short-term loans secured by wages. Funeral insurance can be provided directly by a commercial firm or nonprofit organizations linked to a commercial provider. Also, well-managed burial societies operated by churches or closely knit communities can serve a similar function. The ability of MFIs to provide other products will be circumscribed by the regulations governing their legal status.

Under certain conditions, there may be scope for a special loan product for microentrepreneurs who are caring for orphans and helping those affected by HIV/AIDS. For example, loans might be extended to persons who are committed to caring for abandoned and/or terminally ill members of their rural community. In an unstable economic environment, this type of loan ought to be for enterprises that involve products or services with a relatively stable market.

New activities should be implemented using an operations research or pilot approach to test their feasibility. In these cases, the feasibility of the products or services in terms of acceptability and impact, as well as costs, should be determined. In addition, existing programs should be assessed to determine their outreach to HIV/AIDS-affected households and their impact on these households, with a view to improving program performance. Similar to this study, the respondents should not be limited to those who remain in the program. Information from program leavers and nonparticipants meeting program eligibility requirements facilitates identification of program impacts.

\section{Additional Studies}

The findings have implications for future studies. First, studies similar to this one ought to be undertaken in a more stable economic environment. In such instances, the economic impacts of HIV/AIDS on households and of microfinance on affected clients may be more apparent, since these will not be commingled with negative macroeconomic factors. These studies might try to distinguish between microfinance as an intervention before and after a household is affected by HIV/AIDS.

\footnotetext{
${ }^{15}$ See an outstanding paper by C. Dunford (2001) that provides examples of MFIs integrating education and a discussion of institutional issues.
} 
Second, methodologically rigorous longitudinal studies should be undertaken to better understand the distribution of HIV-affectedness, the ways affected households are negatively impacted, and ways these households respond to the negative impacts. The longitudinal studies would permit a better understanding of the sequence of negative impacts and the sequence of the types of responses, and how these might differ by household characteristics, such as per capita income level. The results would better enable development organizations to develop appropriate mitigation measures. 
Hgrizons

Appendix A

\section{Summary of the Key Findings of the Aims Assessment of Zambuko}

\section{Microentrepreneurs and Their Households}

The profile of Zambuko clients shows that among those interviewed in 1997, approximately twothirds of the new clients and half of the old clients were from households under the poverty line of US\$2 or less a day per person. The typical client in the survey is a married female about 41 years old, with seven to eight years of education. An important finding is that between 1997 and 1999 , nearly half of the client sample had an increase in the proportion of household members who were not economically active. The tendency toward a higher economic dependency ratio partially reflected the dependency status of individuals who joined the respondents' households during the study period. Twelve percent of the households of the client respondents took in a sick person or a person from a household that had experienced illness or death.

In analyzing factors that were significantly associated with the movement of the 1999 respondent households out of poverty, the results indicted that this was primarily related to a reduced number of household members and lower dependency ratios. Since the definition of poverty was primarily based on per capita per day income, size of the household and economic dependency ratios influenced whether a household moved out of extreme poverty or moved into poverty.

\section{Clients' Use of Credit}

The cumulative sum of all loans borrowed from Zambuko was Z $\$ 10,052$ for those respondents who had taken at least one loan since 1997, referred to as continuing clients. This amount was equivalent to less than US\$650 at the time they borrowed. Sixty percent of the continuing clients had taken three or more loans from Zambuko. In contrast, those client respondents who had not taken a loan since the 1997 interview, referred to as departing clients, had taken loans that averaged $\mathrm{Z} \$ 2,921$, which was equivalent to US\$295 in 1997. Approximately 60 percent of the departing clients had taken only one loan.

In 1997 the average size of the last loan was equivalent to 20 to 25 percent of the client's monthly net revenue from the enterprise that secured the loan, and approximately 12 percent of the client household's total monthly income. Thus, the loan size was relatively small in terms of total household income. This suggests that money from other sources might be drawn on to assist with repaying the loan. 
Approximately half of the client respondents used their loans in 1997 exclusively for their enterprise. The other half used a portion for savings or household needs and the rest for their enterprise. The use of funds was not significantly related to the timely repayment of the loan.

In 1997, approximately 60 percent of the client respondents reported that if they had not received a loan from Zambuko they would not have made such expenditures. Among those who had taken a loan since then, half of them reported that they would not have made such expenditures if they had not received a loan from Zambuko.

There was little evidence that microentrepreneurs have access to other sources of credit for their enterprises and households. Other than microfinance organizations, the main source of credit was from businesses that sell furniture, appliances, and other types of durable assets on a hire-purchase arrangement. The assessment found that the provision of credit by the formal sector is extremely limited, suggesting potential expansion, especially when the economy improves.

\section{Program Impacts}

The analyses of the survey data that controlled for specific initial differences make a strong case that Zambuko's program has a positive impact. The results further indicate that the impacts tend to vary among clients based on whether or not they had remained in the program. In some areas, the analysis suggests program impact only among continuing clients, departing clients, or those who were continuing clients who had received more than one loan at the time of the 1997 interview, referred to as repeat continuing clients. In addition, the analysis suggests that Zambuko's program has had a positive impact on extremely poor households, especially among clients who remained in the program. On a number of the impact variables tested, however, the data suggested neither a positive nor negative impact.

\section{Household level}

Loans provide a lump sum of money that clients tend to use for their enterprise. The generation of profits from the use of the loans and better management of financial resources are likely to explain the ability of client's households to make lump sum expenditures. At the household level, the impact on education of boys ages 6 to 16 appears to be widely spread across continuing and departing clients, including those who were extremely poor. The data also suggest that participation in Zambuko increased the probability of continuing clients and departing clients acquiring a stove, and continuing clients acquiring a refrigerator. Participation was also found to be strongly related to the amount of money repeat continuing client households had spent on household durable assets. In addition, the data suggest that program participation positively affected the value of assistance continuing client households provided to non-household members for funeral-related expenditures.

The results also suggest impacts at the household level on food consumption among the extremely poor and diversification of income sources among departing clients. Better management of financial resources is likely to explain the increase in the frequency that meat, chicken or fish, and 


\section{Hgrizons}

milk were consumed in the households of extremely poor continuing clients. Also, the data on diversification of income sources among departing clients suggest that loans enabled these households to gain an additional income source.

The analysis did not suggest that participation in Zambuko's program had an impact on the level of monthly household income, the value of assistance given to non-household members, education of girls ages 6 to 16, education of girls and boys ages 6 to 21, or expenditures on housing improvements, nor on acquisition of a television, electric fan, or means of transport. Thus, the study reveals the areas where lump sum expenditures are most likely to occur and that total household income does not appear to be significantly influenced by program participation.

\section{Enterprise level}

At the enterprise level, the data reveal that the net revenue of the enterprises often did not keep pace with inflation. No significant differences were found in the level of net revenue in all of the household's enterprises, nor in indicators of employment in the enterprises. However, for the enterprise that secured the loan and against which the non-clients were matched, the results suggest that Zambuko had a positive impact on the 1999 net revenue of the matched enterprise of repeat continuing clients. Also, participation in Zambuko's program appears to be related to the 1999 value of all of the household's enterprise assets for repeat departing clients, that is, those who had more than one loan in 1997 but had not taken an additional loan since the 1997 interview.

The data on enterprise net revenue involved comparing the month prior to the interviews. Thus, they do not capture the variation in levels income 1997 until the month prior to the interview in 1999. This helps to explain why impacts might occur at the household level even though the enterprise net revenue did not increase in value when adjusted for inflation.

\section{Individual level}

The analysis of the survey data suggest that participation in Zambuko's program had a positive impact on clients' having an individual savings account and on the number of ways extreme poor continuing clients saved. Both of these imply that participation in a program that does not contain a savings component nevertheless has an impact on the way people save.

The case study findings support the hypotheses that participation in a microfinance program can lead to greater self-esteem and self-confidence and also enhances a client's ability to plan for the future. The greater self-esteem and self-confidence appear to be associated with clients' increased ability to manage their enterprise, meet the financial demands of the household, and acquire assets. 


\section{Implications}

The assessment findings and conclusions have implications for microfinance institutions (MFIs) in Zimbabwe. The implications may also have broader applicability.

\section{Influence of the macroenvironment}

High inflation is likely to place economic stress on MFIs as well as households. For MFIs, the loan money repaid has a lower real value than the money borrowed. Also, interest rates may not keep pace with inflation. Therefore, a MFI is likely to suffer as the money received has less value than the money paid out. Over time, this may lead to an erosion of the MFI's capital base. The findings suggest that the fees charged in addition to the interest rate should be increased on a regular basis to keep pace with inflation. For clients, inflation is likely to put economic stress on their enterprise, which makes it difficult to increase the real value of their enterprise net revenue, which in turn may affect the household's allocation of income. The likely negative effect of high inflation on MFIs and clients suggests that caution should be exercised in the establishment of new microfinance programs and expansion of existing programs. An inflationary environment also implies that MFIs may be faced with decisions related to the level of services that can and should be provided.

\section{Financial products and terms}

The assessment results suggest that there may be a market for shorter-term loans. Many microentrepreneurs join an MFI program to test whether a credit program is appropriate for them. The data reveal that 60 percent of the client respondents who did not seek another loan after 1997 had received only one loan. Also, nearly half of the clients are traders and even those in manufacturing did not tend to invest their loan funds in an enterprise asset. Traders in particular have rather rapid turnaround times, and loans of four to six month duration appear to be more suited to their needs.

The findings also suggest that there is a dearth of financial services accessible to microentrepreneurs' households for non-enterprise investments. There may be a niche market for loans specifically related to the building of rental units by those who own their homes. These loans would most likely require a repayment period longer than one year.

Given that repayment problems were not found to be associated with the use of some of the loan funds outside the enterprise, it is worth exploring the feasibility of offering loans secured by an enterprise or another source of income for educational or emergency needs. Also, there may be a demand for savings accounts that are designated for limited uses, such as educational expenses. While in general, there does not appear to be a lack of access to savings services in these key urban areas, restricted access accounts might help individuals set aside money for specific lump sum needs. 


\section{Hgrizons}

\section{Business management training}

The case studies and survey data on business management training reveal that microentrepreneurs value and benefit from basic business management training. There appears to be an unmet demand for this type of training that is appropriate to low-income microentrepreneurs. MFIs in Zimbabwe may want to pilot a training product focused on this target group to determine if it can be a financially sustainable service. Or, there may be scope for MFIs in Zimbabwe to establish a partnership with an existing business management training organization that can offer training appropriate for microentrepreneurs.

\section{Program leavers}

Clients have left the Zambuko program for a number of reasons. Clients leave due to difficulties repaying the loan, and this departure may be either voluntary or coerced. Others leave because they move outside the program's catchment area. Especially during periods of instability in the economy and household, a microentrepreneur might be satisfied with the program but not have an obvious viable use for credit at a given time. He or she may want to "rest" for a time before taking another loan. The value of an MFI program like Zambuko is that it provides access to credit otherwise not available to poor households in Zimbabwe.

\section{Implications for future assessments}

Some key lessons were learned in the conduct of this assessment. These lessons may be useful not only to the microfinance industry but also other types of programs concerned with measuring their results.

First, the experience highlighted that care ought to be used in setting increased household income as an indicator of program results. While many programs aimed at the disadvantaged and poor often seek to increase household income, a number of non-program factors can influence household income levels irrespective of the program. Therefore, it might be more reasonable to expect a program to increase a particular source of income, rather than total household income. As suggested by this study, income is difficult to measure precisely. Therefore, a multi-pronged approach that considers income and indicators of expenditure flows as well as asset accumulation help to overcome this weakness.

Second, results of the analyses of the survey data reinforce the importance of using a non-client control group. This group represents what occurred among non-program participants and enables the analysts to more convincingly identify the specific impacts of program participation.

Third, the data on changes in the household's poverty status indicate that the definition influences the results. This suggests the need for the microfinance industry to agree on some common approaches to defining and discussing poverty. 
Microfinance, Households, and HIVIAIDS

\section{Appendix B}

\section{Summary of Study Design and Methods}

Understanding the study design, methods and sites provides a background for understanding the study's results. This appendix summarizes the survey design, sampling, final database, and comparison groups used in the analyses. It also includes an explanation of the statistical tests used to suggest impacts. Then the appendix explains the approaches used for the qualitative components of the study. ${ }^{16}$

\section{The Survey}

The survey consisted of interviewing a randomly selected group of clients and non-client microentrepreneurs. The survey questionnaire was preceded by a qualitative study and pre- and pilot tests of the questionnaire. In 1999, preparations for the second round of data collection involved inclusion of key questions related to illness and death and location of the 1997 respondents. Prior to each survey round, the enumerators attended a one-week training session. During the data collection and entry phases, additional measures were taken to help ensure the quality of the data. The analysis of the data involved comparing clients and non-clients and categorizing households according to whether they were possibly HIV/AIDS-affected. This permitted statistical tests to indicate the impact of microfinance and of HIV/AIDS on clients and on their households and enterprises.

\section{Sampling}

When the sample design was developed in April 1997, Zambuko had a number of branches and satellite offices. Logistics and cost implications dictated limiting the number of geographic areas covered by the survey. After a discussion with the executive director of Zambuko, it was decided that the sample of clients should be from Bulawayo (excluding the new Gwanda office), Harare, and Chitungwiza, since these were established programs with some clients who had received more than one loan, and the majority of clients were from these geographic areas. In addition, Mutare was included as representing Zambuko's offices in the smaller cities. ${ }^{17}$ Thereafter, using lists of current clients from the four offices, a sample of 244 new clients was randomly drawn from a list of 1,281 persons who had received their first loans between May 1 and June 30, 1997. All 196 repeat borrowers who had received a loan between April 1 and June 30, 1997, were included in the sample.

\footnotetext{
${ }^{16}$ More detailed information on the survey methods and procedures are in the AIMS report (Barnes 2001).

${ }^{17}$ A preliminary analysis of this sub-sample in 1999 indicated that they did not vary significantly from others in the client sample on assets, a key indicator of poverty level.
} 


\section{Hgrizons}

Zambuko provides loans to individuals who have enterprises, and the loans are supposed to be used for a designated enterprise. The design centered on inclusion of a sample of non-client microentrepreneurs as the quasi-experimental design control group to permit a comparison of differences in the impact variables between clients and non-clients, and thus facilitate the identification of the impacts of Zambuko's program. The non-clients were matched with clients on the basis of gender, enterprise sector, and geographic location (within walking distance of the client with whom they were matched). In addition, to be included in the study, non-client microentrepreneurs had to own an enterprise that was at least six months old and not be employed elsewhere on a full-time basis, mirroring basic criteria used by Zambuko. Thus, care was taken to help ensure that the client and non-client samples shared key characteristics. Also, non-client microentrepreneurs who had received loans for their enterprises from other formal institutions were excluded. This helped to ensure that those selected were an appropriate control group.

\section{Respondents included in the final analysis}

Care was taken in relocation of the respondents in 1999, resulting in re-interviewing 88 percent of the clients and 86 percent of the non-clients from the 1997 sample. These rates include 36 (six percent) substitute respondents when the respondent was not available during the survey period. On certain questions, the responses of the substitutes are excluded from the analysis. When the body of the report refers to client and non-client respondents, the findings include information from the substitutes except on the questions on individual-level impacts.

The final analysis excluded those who were case study respondents, the 14 non-clients who had taken loans from Zambuko since 1997, and a few inappropriate substitute respondents. Thus out of the 599 persons interviewed in 1999, the final database used for the analysis was 579 .

Approximately 80 percent of the respondents were women since most of Zambuko's clients are women.

\section{Statistical methods}

The survey data were analyzed using a number of statistical methods. In particular, two statistical methods were used that take into account the possibility that the comparison groups differed initially on a particular impact variable. First, the ANOVA gain score analysis method centers on the change in each comparison group on a particular variable, rather than on the absolute values for each group. As such, it does not assume that the two groups were similar in 1997 on the variable analyzed. When the score involves a numerical value, it is based on the 1999 findings minus the 1997 for each respondent. ${ }^{18}$ The ANOVA gain score analysis includes determining whether the results differ significantly between any two of the comparison groups, taking into account the

\footnotetext{
${ }^{18}$ In a few instances, the gain score varies slightly from the value of 1999 minus 1997 for the comparison group due to rounding each of the values.
} 
grand mean across all respondents. The gain score approach used in the analysis does not attempt to take into account the influences of other factors.

The second method used was ANCOVA. It includes the measure from the first survey in the model in the form of a linear regression. ANCOVA analysis controls for differences between the analytic groups in 1997 on specified variables, differences that might have influenced the relationship between program participation and the values found in 1999 on the impact variables. The ANCOVA statistically matches observations in the analytic groups on their 1997 measures and other covariates, and then uses the average difference between the matched groups on their 1999 values to estimate the treatment effect (Reichardt and Mark 1998). The ANCOVA test may introduce bias with random measurement error in the 1997 scores used in the analysis and when irrelevant covariates are used (Reichardt 1979). Hence, the results suggest areas of impact and make a strong plausible case for where impacts most likely occurred.

As discussed above, one reason for including covariates or independent variables is to explicitly control for specific values or factors that may affect change in the impact variable. A second reason for including multiple covariates is that the analysis will suggest whether a specific independent variable significantly influenced the differences found in 1999. The 1997 values were used for each covariate included in the ANCOVA analysis of the impact variables.

The selection of covariates was guided by the factors thought to be most closely associated with the impact variables. In addition to the 1997 values on the variable analyzed, the ANCOVA analyses used the following set of covariates:

- Extremely poor compared to all others (i.e., moderately poor and non-poor).

- Non-poor compared to the poor (i.e., extremely poor and moderately poor).

- Household economic dependency ratio.

- Loan status (repeat borrowers compared to all other respondents).

- Those affected by illness or death in 1997 compared to those not affected.

\section{Other considerations}

Several of the impact variables are measured in terms of Zimbabwe dollar values. However, during the assessment period, inflation as indicated by the Consumer Price Index (CPI) was high, and the Zimbabwe dollar decreased in value. Thus, on variables that measured last month's expenditures and income, the data provided in 1999 were deflated to 1997 constant values. ${ }^{19}$

\footnotetext{
${ }^{19}$ The CPI was 488.5 in September 1997 and 1091.6 in September 1999. Using September 1997 as the base (September $1997=100$ ), the CPI value in September 1999 was 223.47. The results show that the value had more than doubled since 1997. Thus, the formula used deflated the 1999 values by 2.235 . For example, the monthly income of clients averaged Z\$9,071 in September 1999; when deflated $(9,071$ divided by 2.235) to real income values or 1997 constant values, the average income was Z $\$ 4,059$.
} 


\section{Hgrizons}

When an analysis is based on the mean value for a group, it might be influenced by a few responses that are either extremely high or extremely low. The initial data verification and cleaning process had already determined if the outliers represented data entry errors or special cases. The analyses of variables in dollar terms is normally given without outliers, values more than three standard deviations ("z-scores") from the mean were removed.

Another consideration was the treatment of missing data. In particular, respondents often could not provide an estimate in response to questions that center on monetary values, such as the amount of income earned by a household member last month. These cases are treated as missing values and are not included in the analysis. This leads to the $\mathrm{n}$ values, that is, the number of persons reporting, varying among the analyses of specific variables. For the ANCOVA analysis, in a few cases the data were missing on a covariate. Therefore, the household was dropped from the ANCOVA analysis, and the respondent base for the t-tests and gain score analyses was adjusted to include only those respondents included in the ANCOVA.

\section{Focus Groups and Key Interviews}

\section{Focus groups with borrowers}

Two types of borrowers were invited to attend the focus groups: those who were clients in late 2000 and those who had participated in the survey and taken a loan between 1997 and 1999. It was anticipated that more than half of those invited would not attend the session due to conflicting demands on their time. Also, since most of Zambuko's clients are women and most of the clients in the survey were women, it was decided to invite mainly women.

The lists of clients from Harare, Chitungwiza, Bulawayo, and Mutare who had participated in the survey and who had received at least one loan between 1997 and 1999 were studied to identify the women. For each session, up to 30 persons were randomly selected and mailed an invitation. The invitation explained that participation was voluntary, and there would be no direct benefit from participation nor would it affect receipt of financial services. It also stated that the information collected would not be attributed to individuals, their names would not appear in any document, and they might withdraw from participation if they did not want to discuss a particular topic.

In order to reflect more recent events and circumstances, lists of individuals who had loans in late 2000 were obtained from Zambuko for the Kuwadzana Trust Bank, Chitungwiza, Highfield, and Mbare branch offices under the Harare Regional Office, Mpopoma branch office in Bulawayo, and the Mutare City branch office. With the exception of the Mbare list, the next step involved identification of the females. Then, a random sample was drawn to select 30 individuals from each branch to be invited to the focus group. They were sent letters of invitation similar to those sent to the survey clients.

The focus group sessions with current clients centered on the following key questions. The first two stimulated discussion of illness and death, and of HIV/AIDS. The questions were devised to place illness and death in the broader context, and then to narrow the focus of the discussion. 
- How are loan co-guarantee groups formed and reformed? What criteria are used by members of a loan group for selecting members?

- What were the main reasons clients had difficulty repaying their loans on time in 2000 ? (Then a ranking of those reasons).

- Are there ideas and suggestions about services that might help those who support or take care of individuals with a long illness and those affected by death in their household?

The focus groups with former clients included the following key questions.

- What were your main objectives when you joined Zambuko and were these achieved?

- Why did you leave the program?

- Are there ideas and suggestions about services that might help those who support or take care of individuals with a long illness and those affected by death in their household?

A set of key probe questions were also asked. These included the following:

- If a member had difficulty repaying a loan due to long illness and death in the family, how does the group respond?

- Would there be a difference between a Zambuko client and a non-client microentrepreneur in their ability to cope with serious illness or death in their household? Participants were asked to provide concrete examples from their experience.

To stimulate contributions from all participants on the question related to the main reasons why clients had difficulty repaying their loans on time in 2000, participants were asked to think about their response and then jot it down on a piece of paper. They were then asked to share their response with the group.

All focus group sessions with the randomly selected sample were held in a "public" place and in a room that was conducive to a private, confidential discussion, without the presence of outsiders. Each session began by the facilitator reading the protocol from the invitation.

Including the pilot tests, the focus group sessions included 155 current and former clients. Approximately 40 percent of the randomly selected invitees attended. Individuals from 26 loan coguarantee groups participated. Their groups varied in size from five to 38 members and were formed between 1996 and 1998 with a total of 232 original members. 
Table 9 Focus groups with clients

\begin{tabular}{|c|c|c|c|c|}
\hline \multirow{2}{*}{ Place } & \multicolumn{2}{|c|}{ Number } & \multirow{2}{*}{ Client status } & \multirow{2}{*}{ Loan type } \\
\hline & Attended & Invited & & \\
\hline $\begin{array}{l}\text { Harare: } \\
\text { pilot test }\end{array}$ & 21 & NA & $\begin{array}{l}\text { Current clients (women and } \\
\text { men) }\end{array}$ & Group loans \\
\hline $\begin{array}{l}\text { Chitungwiza: } \\
\text { pilot test }\end{array}$ & 26 & NA & Current clients (women) & Group loans \\
\hline Harare & 7 & 21 & $\begin{array}{l}\text { Survey clients (women) } \\
\text { drop-outs/resting-6 }\end{array}$ & Group loans \\
\hline $\begin{array}{l}\text { Harare- } \\
\text { Highfield }\end{array}$ & 10 & 30 & Current clients (women) & Group loans \\
\hline $\begin{array}{l}\text { Harare- } \\
\text { Mbare }\end{array}$ & 22 & 30 & $\begin{array}{l}\text { Current clients (women and } \\
\text { men) }\end{array}$ & Group loans \\
\hline $\begin{array}{l}\text { Harare- Trust } \\
\text { Bank, } \\
\text { Kuwadzana }\end{array}$ & 9 & 30 & $\begin{array}{l}\text { Current clients (women) } \\
\text { Drop-outs/resting-3 women }\end{array}$ & $\begin{array}{l}\text { Group loans, special } \\
\text { methodology }\end{array}$ \\
\hline Chitungwiza & 11 & 30 & $\begin{array}{l}\text { Survey clients (women) } \\
\text { drop-outs-7 } \\
\text { current clients-4 }\end{array}$ & Group loans \\
\hline Chitungwiza & 9 & 30 & Current clients (women) & Group loans \\
\hline Mutare & 7 & 21 & $\begin{array}{l}\text { Survey clients (women) } \\
\text { drop-outs/resting-4 } \\
\text { current clients -3 }\end{array}$ & $\begin{array}{l}\text { Individual and group } \\
\text { loans }\end{array}$ \\
\hline Mutare & 10 & 30 & $\begin{array}{l}\text { Current clients (8 women and } \\
2 \text { men) }\end{array}$ & $\begin{array}{l}\text { Individual and group } \\
\text { loans }\end{array}$ \\
\hline Bulawayo & 7 & 19 & $\begin{array}{l}\text { Survey clients (women) } \\
\text { drop-outs/resting-6 } \\
\text { current clients-1 }\end{array}$ & $\begin{array}{l}\text { Individual and group } \\
\text { loans }\end{array}$ \\
\hline Bulawayo & 16 & 30 & Current clients (women) & $\begin{array}{l}\text { Individual and group } \\
\text { loans }\end{array}$ \\
\hline
\end{tabular}

\section{Focus groups with branch supervisors and loan officers}

Four sessions were planned and successfully completed with Zambuko officers. Meetings were held with business development officers (loan officers) and branch supervisors from the Harare, Bulawayo, and Mutare regions, plus the Chitungwiza branch office. These sessions were held in 
Zambuko offices. A total of 33 business development officers and branch managers attended. The sessions began by explaining that their participation was voluntary and that the information provided would not be attributable to individuals or branch offices. Then the sessions opened with an exercise led by the facilitator with the objective of demonstrating that individuals may see the same thing differently. ${ }^{20}$ A set of predetermined key questions stimulated the discussion on issues related to HIV/AIDS. The questions centered on criteria for joining and remaining in groups, and the reasons why clients had difficulty repaying their loans. The discussion was interspersed with probe questions related to HIV/AIDS. The sessions ended with a discussion of ideas and suggestions for services to help those who take care of the terminally ill or support people affected by HIV/AIDS. The principal researcher led the discussions, with the local team members assisting with note taking.

\section{Interviews with key Zambuko managers}

The principal researcher conducted a series of interviews with key Zambuko managers. In particular, she talked with the executive director; regional officers for Harare, Bulawayo, and Mutare; and the coordinator of the Trust Bank program. These interviews centered on the following questions:

- What has been the impact of HIV/AIDS on their financial portfolio and operations?

- What current and possibly future policies mitigate the potential negative impact of HIV/AIDS on their financial portfolio?

- What measures has the program taken to mitigate the economic impact of HIV/AIDS on clients?

\footnotetext{
${ }^{20}$ This was not done in Mutare, where the session was facilitated only by the principal investigator.
} 


\section{Appendix C}

\section{Additional Tables}

Table 10 Types of affectedness among respondents possibly HIV-affected, 19951999 (percentage)

\begin{tabular}{|c|c|c|c|}
\hline Types of HIV Affectedness & $\begin{array}{l}\text { Clients } \\
n=134\end{array}$ & $\begin{array}{c}\text { Non-clients } \\
n=94\end{array}$ & $\begin{array}{c}\text { Total } \\
n=228\end{array}$ \\
\hline $\begin{array}{l}\text { 1997-1999 illness or death of non-household } \\
\text { member }\end{array}$ & 38 & 32 & 36 \\
\hline $\begin{array}{l}\text { 1997-1999 illness of spouse, self, or other } \\
\text { member } 20 \text { years or older }\end{array}$ & 47 & 55 & 50 \\
\hline $\begin{array}{l}\text { 1997-1999 death of spouse or other member } 20 \\
\text { years or older }\end{array}$ & 34 & 24 & 30 \\
\hline 1999 chronically ill member & 22 & 19 & 21 \\
\hline $\begin{array}{l}1999 \text { new household member due to illness or } \\
\text { death }\end{array}$ & 30 & 27 & 29 \\
\hline 1995-1997 illness in household ${ }^{b}$ & 35 & 23 & 30 \\
\hline 1995-1997 illness and death in household ${ }^{c}$ & 53 & 41 & 45 \\
\hline
\end{tabular}


Table 11 Data on variables related to analysis of impacts of affectedness on households

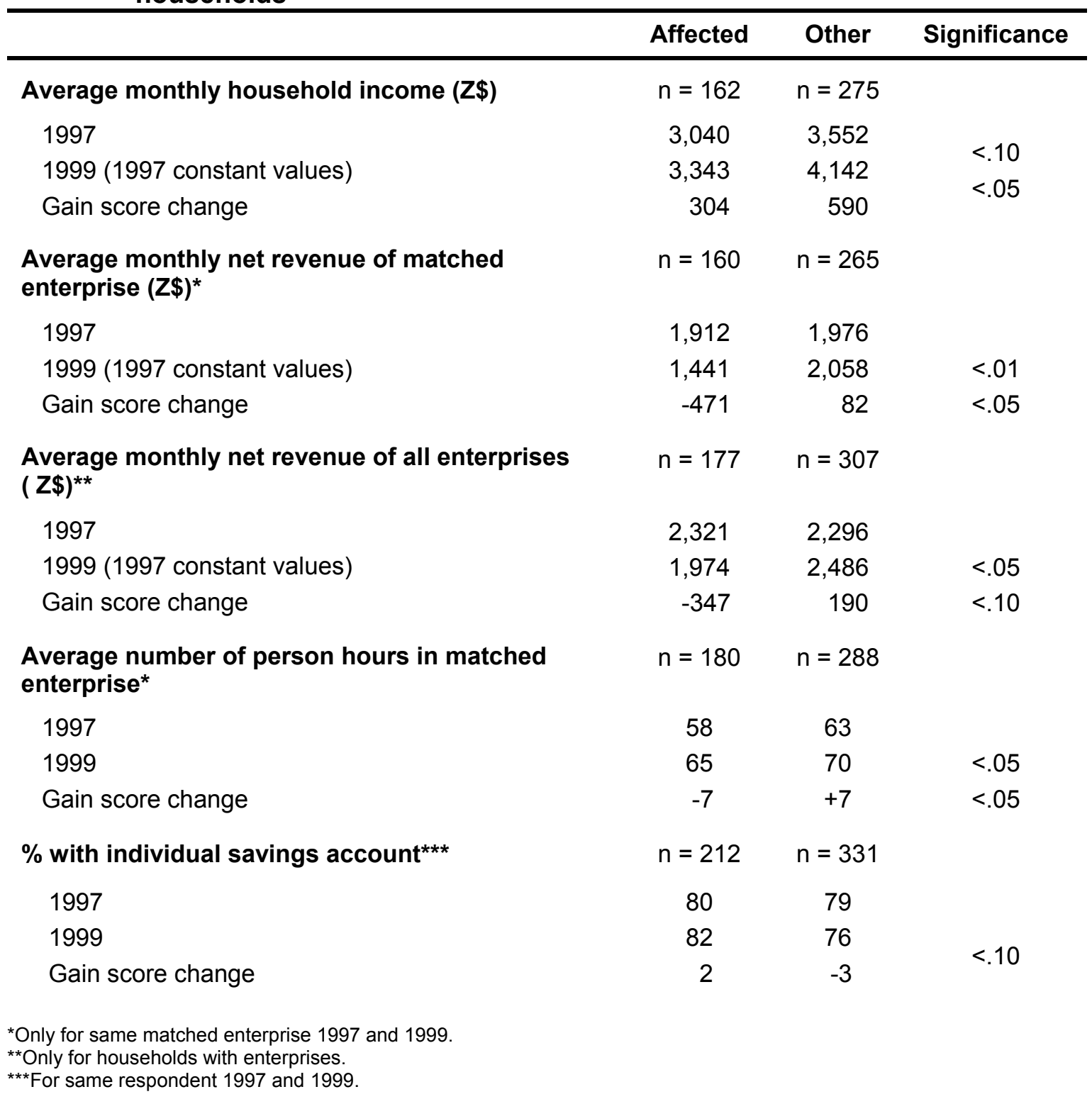




\section{Hgrizons}

Table 12 Additional data on affected households and other households

\begin{tabular}{|c|c|c|}
\hline & Affected & Other \\
\hline Affectedness index & $n=228$ & $\mathrm{n}=351$ \\
\hline $\begin{array}{l}\text { Average number of ways affected by illness/death, } \\
\text { 1995-1999 }\end{array}$ & 2.5 & 1.1 \\
\hline Respondent's age, 1997 & $n=209$ & $\mathrm{n}=330$ \\
\hline Average age & 39 & 38 \\
\hline \multicolumn{3}{|l|}{ Marital status of respondent } \\
\hline Proportion widowed $^{a}$ & $n=210$ & $\mathrm{n}=331$ \\
\hline Widow 1997 and 1999 & 11 & 11 \\
\hline Widow 1997, married 1999 & 3 & 3 \\
\hline Widowed since 1997 & 13 & 0 \\
\hline Other marital status & 73 & 86 \\
\hline Household size & $\mathrm{n}=228$ & $\mathrm{n}=351$ \\
\hline 1997 & 5.6 & 5.6 \\
\hline 1999 & 5.8 & 5.6 \\
\hline Gain score change & .2 & 0 \\
\hline Per capita household monthly income (w/o outliers) & $\mathrm{n}=165$ & $n=273$ \\
\hline $1997^{\mathrm{C}}$ & 692 & 825 \\
\hline 1999 (deflated to 1997 constant values) & 665 & 706 \\
\hline Gain score change & -27 & -118 \\
\hline \multicolumn{3}{|l|}{ Education of children in household } \\
\hline$\%$ of household's boys ages 6-16 enrolled in school & $\mathrm{n}=107$ & $\mathrm{n}=151$ \\
\hline $1997^{d}$ & 92 & 96 \\
\hline 1999 & 98 & 96 \\
\hline Gain score change $^{\mathrm{b}}$ & 6 & 0 \\
\hline$\%$ of household's girls ages 6-16 enrolled in school & $\mathrm{n}=118$ & $\mathrm{n}=161$ \\
\hline 1997 & 94 & 94 \\
\hline 1999 & 93 & 92 \\
\hline Gain score change & -1 & -3 \\
\hline $\begin{array}{l}\% \text { of household's children ages } 6-21 \text { enrolled in } \\
\text { school }\end{array}$ & $\mathrm{n}=179$ & $\mathrm{n}=267$ \\
\hline 1997 & 78 & 78 \\
\hline 1999 & 78 & 77 \\
\hline Gain score change & 0 & -1 \\
\hline
\end{tabular}


Average number of days in last week consumed specified foods in household
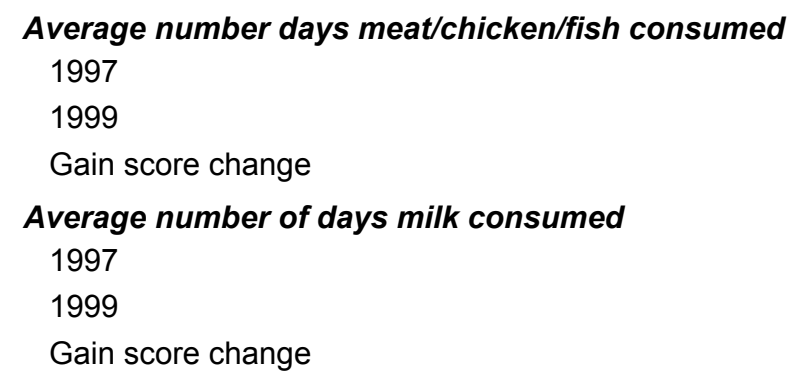

Average number of days eggs consumed 1997 1999 Gain score change

$\begin{array}{cc}\mathrm{n}=225 & \mathrm{n}=344 \\ 4.1 & 4.2 \\ 4.3 & 4.5 \\ .2 & .3 \\ \mathrm{n}=224 & \mathrm{n}=343 \\ 1.6 & 1.7 \\ 1.1 & 1.2 \\ -.4 & -.5 \\ \mathrm{n}=224 & \mathrm{n}=344 \\ 2.0 & 2.2 \\ 1.7 & 1.9 \\ -.3 & -.4 \\ & \\ \mathrm{n}=228 & \mathrm{n}=351 \\ 6 & 9 \\ 61 & 53 \\ 21 & 17 \\ 12 & 21 \\ \mathrm{n}=221 & \mathrm{n}=343 \\ 249 & 247 \\ 318 & 360 \\ 69 & 113 \\ \mathrm{n}=222 & \mathrm{n}=344 \\ 67 & 51 \\ 70 & 55 \\ 4 & 4\end{array}$

Assistance to non-household members

Changes in giving assistance (percent) ${ }^{2}$

No assistance 1997 nor 1999

Assistance both 1997 and 1999

Assistance in 1997, not 1999

Assistance in 1999, not 1997

Average $Z \$$ value of assistance (all reasons) 1997

1999 (deflated to 1997 constant values)

Gain score change

Average $Z \$$ value for funeral-related assistance 1997

1999 (deflated to 1997 constant values)

Gain score

$\begin{array}{cc}\mathrm{n}=180 & \mathrm{n}=288 \\ 58 & 63 \\ 65 & 70 \\ -7 & +7 \\ \mathrm{n}=198 & \mathrm{n}=330 \\ 73 & 74 \\ 81 & 87 \\ 7 & 14\end{array}$




\section{Hgrizons}

Average total hours of respondent in household
enterprises*
$1997^{d}$
1999
Gain score

Average total hours worked by other household members in household enterprises

1997

1999

Gain score

$\%$ with paid employees in household enterprise(s)

1997

1999

Gain score

$\begin{array}{cc}\mathrm{n}=191 & \mathrm{n}=315 \\ 45 & 49 \\ 41 & 44 \\ -4 & -6 \\ \mathrm{n}=198 & \mathrm{n}=330 \\ & \\ 12 & 12 \\ 19 & 20 \\ 6 & 8 \\ \mathrm{n}=198 & \mathrm{n}=330 \\ 17 & 23 \\ 23 & 28 \\ 6 & 5\end{array}$

Outliers (values 3 standard deviations from the mean) were removed. Same respondent microentrepreneur in 1997 and 1999.

${ }^{a} p \leq .01 .{ }^{b} p \leq .05 .{ }^{c} p \leq .10 .{ }^{d} p \leq .15$. 
Table 13 Distribution of respondent households by poverty level, 1997 and 1999 (percentage)

\begin{tabular}{|c|c|c|c|c|c|}
\hline \multirow[b]{2}{*}{ Poverty Level } & \multicolumn{2}{|c|}{ Possibly HIV-affected } & \multicolumn{2}{|c|}{ Others } & \multirow{2}{*}{$\begin{array}{c}\text { Total } \\
\mathrm{n}=579\end{array}$} \\
\hline & $\begin{array}{l}\text { Clients } \\
n=134\end{array}$ & $\begin{array}{c}\text { Non-clients } \\
n=94\end{array}$ & $\begin{array}{l}\text { Clients } \\
n=204\end{array}$ & $\begin{array}{c}\text { Non-clients } \\
n=147\end{array}$ & \\
\hline \multicolumn{6}{|l|}{$1997^{a}$} \\
\hline Extremely poor & 34 & 46 & 34 & 36 & 36 \\
\hline Moderately poor & 37 & 39 & 31 & 45 & 38 \\
\hline Non-poor & 29 & 15 & 35 & 19 & 26 \\
\hline \multicolumn{6}{|l|}{$1999^{b}$} \\
\hline Extremely poor & 24 & 39 & 23 & 29 & 28 \\
\hline Moderately poor & 45 & 34 & 35 & 28 & 35 \\
\hline Non-poor & 31 & 27 & 42 & 43 & 37 \\
\hline \multicolumn{6}{|c|}{$\begin{array}{l}\text { a Statistically significant differences between the following: } \\
\text { Affected clients and affected non-clients: extremely poor }(p \leq .10) \text { and not poor }(p \leq .01) \text {. } \\
\text { Affected clients and other non-clients: not poor }(p \leq .05) \text {. } \\
\text { Other clients and other non-clients: moderately poor }(p \leq .01) \text { and not poor }(p \leq .01) \text {. } \\
\text { b Statistically significant differences between the following: } \\
\text { - Affected clients and affected non-clients: extremely poor }(p \leq .05) \text { and moderately poor }(p \leq .10) \text {. } \\
\text { - Affected clients and other non-clients: moderately poor }(p \leq .01) \text { and not poor }(p \leq .05) . \\
\quad \text { Affected non-clients and other non-clients: extremely poor }(p \leq .15) \text { and not poor }(p \leq .01) \text {. }\end{array}$} \\
\hline
\end{tabular}


Table 14 Changes in poverty status of respondent households, 1997 and 1999 (percentage)

\begin{tabular}{|c|c|c|c|c|c|}
\hline \multirow[b]{2}{*}{ Poverty Status } & \multicolumn{2}{|c|}{ Possibly HIV-affected } & \multicolumn{2}{|c|}{ Others } & \multirow{2}{*}{$\begin{array}{c}\text { Total } \\
\mathrm{n}=579\end{array}$} \\
\hline & Clients & Non-clients & Clients & Non-clients & \\
\hline 1997 Extremely poor & $\mathrm{n}=45$ & $n=43$ & $\mathrm{n}=69$ & $n=53$ & $n=210$ \\
\hline $\begin{array}{l}\text { \% } 1997 \text { extremely } \\
\text { poor moved upwards }{ }^{a}\end{array}$ & 67 & 44 & 54 & 57 & 55 \\
\hline 1997 Non-poor & $\mathrm{n}=39$ & $n=14$ & $\mathrm{n}=71$ & $\mathrm{n}=28$ & $n=152$ \\
\hline $\begin{array}{l}\% 1997 \text { non-poor to } \\
\text { moderate or extreme } \\
\text { poverty in } 1999^{b}\end{array}$ & 59 & 50 & 38 & 21 & 41 \\
\hline
\end{tabular}

Table 15 Average per capita monthly household income, 1997 and 1999 (Zimbabwe dollars in 1997 adjusted values)*

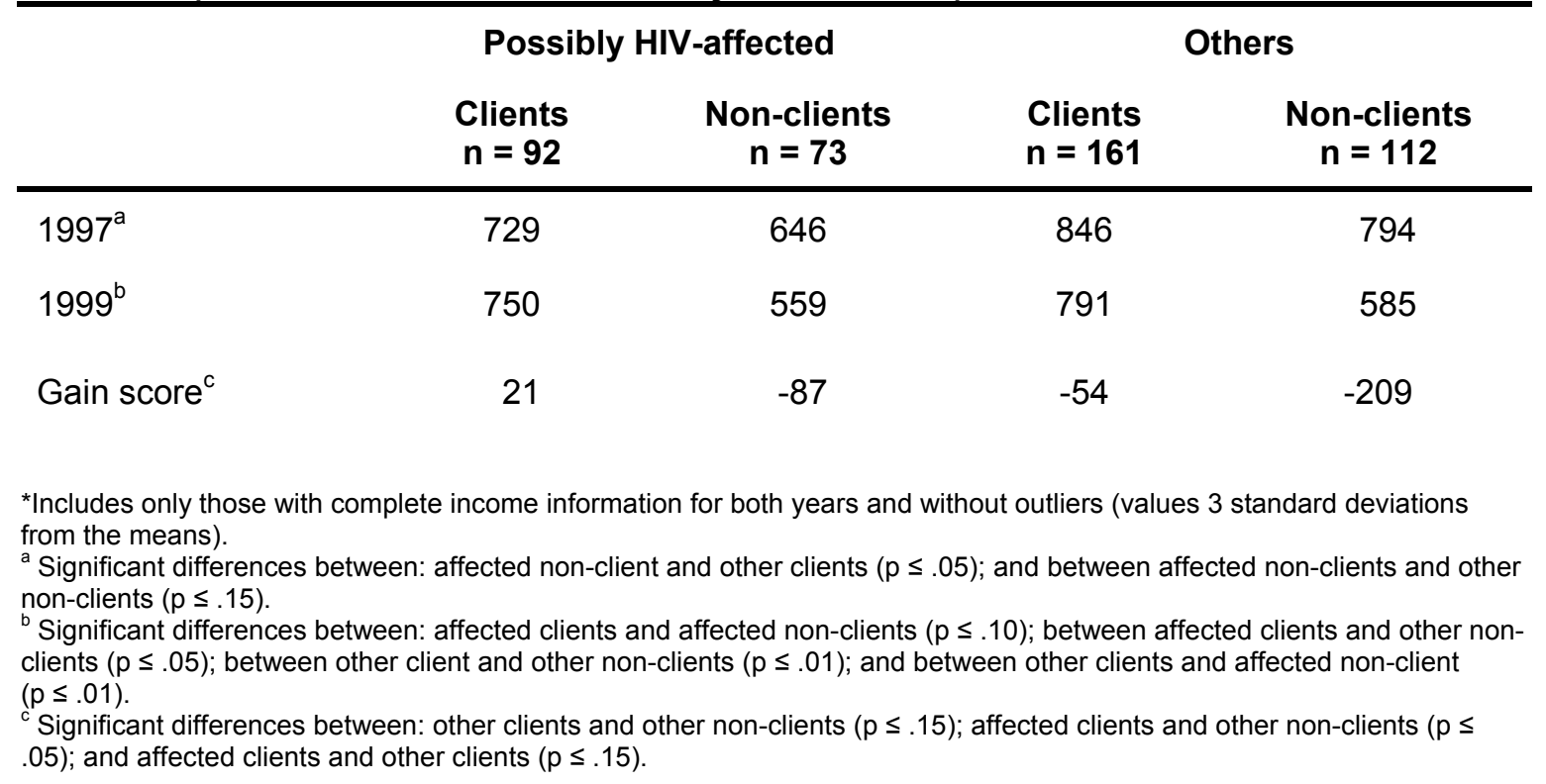


Table 16 Average ratio of enterprise net revenue to total monthly household income $^{*}$

\begin{tabular}{|c|c|c|c|c|}
\hline & \multicolumn{2}{|c|}{ Possibly HIV-affected } & \multicolumn{2}{|c|}{ Others } \\
\hline & $\begin{array}{c}\text { Clients } \\
n=96\end{array}$ & $\begin{array}{c}\text { Non-clients } \\
n=73\end{array}$ & $\begin{array}{l}\text { Clients } \\
n=165\end{array}$ & $\begin{array}{c}\text { Non-clients } \\
n=117\end{array}$ \\
\hline $1997^{\mathrm{a}}$ & 75 & 74 & 67 & 66 \\
\hline 1999 & 56 & 53 & 56 & 58 \\
\hline Gain score ${ }^{b}$ & -20 & -21 & -11 & -8 \\
\hline
\end{tabular}

Table 17 Changes in number of household enterprises, 1999 compared to 1997 (percentage)

\begin{tabular}{lcccc}
\hline $\begin{array}{l}\text { Changes in } \\
\text { Household } \\
\text { Enterprises }\end{array}$ & $\begin{array}{c}\text { Plients } \\
\mathbf{n = 1 3 4}\end{array}$ & $\begin{array}{c}\text { Non-clients } \\
\mathbf{n = 9 4}\end{array}$ & $\begin{array}{c}\text { Clients } \\
\mathbf{n = 2 0 4}\end{array}$ & $\begin{array}{c}\text { Non-clients } \\
\mathbf{n = 1 4 7}\end{array}$ \\
\hline Less/none & 23 & 20 & 17 & 18 \\
Same & 60 & 62 & 67 & 70 \\
More & 17 & 18 & 16 & 12
\end{tabular}


Table 18 Average monthly household income 1997 and 1999 (Zimbabwe dollars in 1997 adjusted values)*

\begin{tabular}{lcccc}
\hline & \multicolumn{2}{c}{ Possibly HIV-affected } & \multicolumn{2}{c}{ Others } \\
$\begin{array}{l}\text { Clients } \\
\mathbf{n}=\mathbf{9 2}\end{array}$ & $\begin{array}{c}\text { Non-clients } \\
\mathbf{n}=\mathbf{7 0}\end{array}$ & $\begin{array}{c}\text { Clients } \\
\mathbf{n}=\mathbf{1 6 0}\end{array}$ & $\begin{array}{c}\text { Non-clients } \\
\mathbf{n}=\mathbf{1 1 5}\end{array}$ \\
\hline $1997^{\mathrm{a}}$ & 3,708 & 2,159 & 3,958 & 2,987 \\
$1999^{\mathrm{b}}$ & 3,943 & 2,553 & 4,125 & 4,165 \\
Gain score $^{\mathrm{c}}$ & 235 & 394 & 167 & 1,178
\end{tabular}

*Includes only those with complete income information for both years, and without the outliers (values 3 standard deviations from the mean).

a Significant differences between: affected clients and affected non-clients ( $p \leq .01)$; affected clients and the other clients ( $p$ $\leq .10)$; other clients and other non-clients $(p \leq .01)$; and affected non-clients and other non-clients $(p \leq .03)$.

${ }^{b}$ Significant differences between: affected clients and affected non-clients $(p \leq .05)$; and affected non-clients and other nonclients $(p \leq .01)$.

${ }^{c}$ Significant differences between: affected clients affected and other non-clients $(p \leq .10)$; and other clients and other nonclients $(p \leq .05)$.

\section{Table 19 Average total net revenue from matched enterprise last month, 1997 and 1999 (Zimbabwe dollars in 1997 constant values)*}

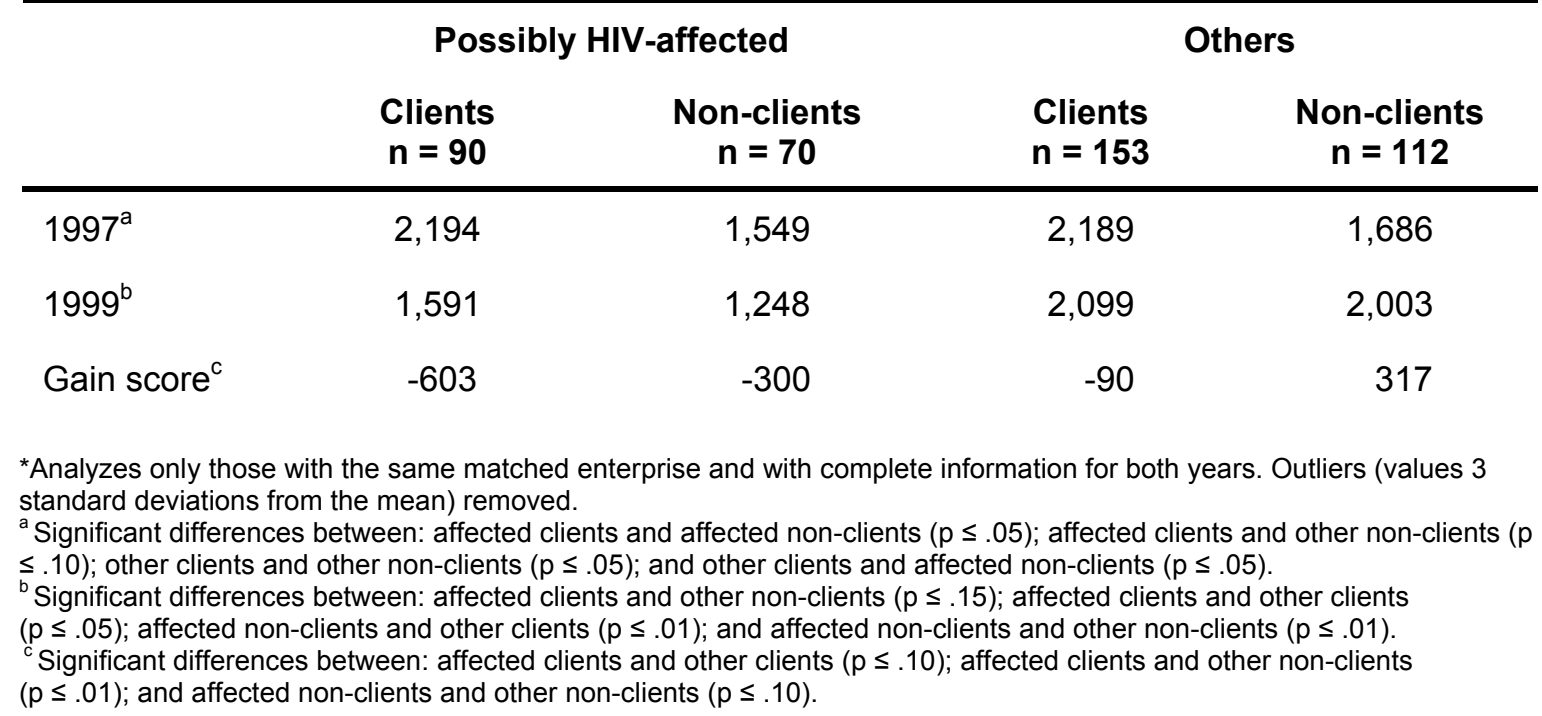


Table 20 Proportion of households with paid employees in their household enterprises

\begin{tabular}{lcccc}
\hline & \multicolumn{2}{c}{ Possibly HIV-affected } & \multicolumn{2}{c}{ Others } \\
& $\begin{array}{l}\text { Clients } \\
\mathbf{n}=\mathbf{1 1 9}\end{array}$ & $\begin{array}{c}\text { Non-clients } \\
\mathbf{n}=\mathbf{7 9}\end{array}$ & $\begin{array}{c}\text { Clients } \\
\mathbf{n}=\mathbf{1 9 3}\end{array}$ & $\begin{array}{c}\text { Non-clients } \\
\mathbf{n}=\mathbf{1 3 7}\end{array}$ \\
\hline $1997^{\mathrm{a}}$ & 20 & 11 & 27 & 16 \\
1999 & 26 & 18 & 28 & 28 \\
Gain score & 6 & 6 & 1 & 12 \\
& & & & \\
a Significant differences between affected clients and affected non-clients $(p \leq .10)$ and between other clients and other non- \\
clients $(p \leq .05)$.
\end{tabular}

Table 21 Average household size and economic dependency ratios*

\begin{tabular}{|c|c|c|c|c|}
\hline & \multicolumn{2}{|c|}{ Possibly HIV-affected } & \multicolumn{2}{|c|}{ Others } \\
\hline & $\begin{array}{l}\text { Clients } \\
n=134\end{array}$ & $\begin{array}{c}\text { Non-clients } \\
n=94\end{array}$ & $\begin{array}{l}\text { Clients } \\
n=204\end{array}$ & $\begin{array}{c}\text { Non-clients } \\
n=147\end{array}$ \\
\hline \multicolumn{5}{|c|}{ Average household size } \\
\hline $1997^{a}$ & 5.9 & 5.2 & 5.7 & 5.4 \\
\hline $1999^{b}$ & 6.2 & 5.4 & 5.8 & 5.4 \\
\hline Gain score & .3 & .2 & .1 & 0 \\
\hline \multicolumn{5}{|c|}{ Economic dependency ratio* } \\
\hline 1997 & 31 & 30 & 30 & 28 \\
\hline $1999^{c}$ & 43 & 37 & 32 & 33 \\
\hline Gain score $^{d}$ & 11 & 7 & 2 & 4 \\
\hline \multicolumn{5}{|c|}{ 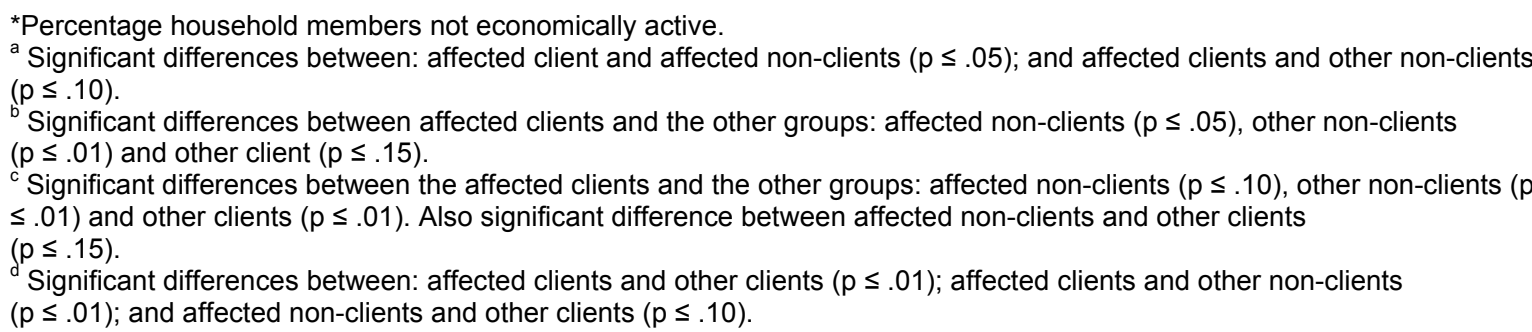 } \\
\hline
\end{tabular}


Table 22 Findings related to the analysis of impacts of microfinance on HIVaffected clients' households and enterprises

\begin{tabular}{|c|c|c|c|c|}
\hline & \multicolumn{2}{|c|}{ Possibly HIV-affected } & \multicolumn{2}{|c|}{ Others } \\
\hline & Clients & $\begin{array}{l}\text { Non- } \\
\text { clients }\end{array}$ & Clients & $\begin{array}{l}\text { Non- } \\
\text { clients }\end{array}$ \\
\hline Average number income sources & $n=133$ & $n=94$ & $n=203$ & $n=147$ \\
\hline $1997^{b}$ & 2.5 & 2.1 & 2.5 & 2.4 \\
\hline $1999^{b}$ & 2.8 & 2.3 & 2.7 & 2.6 \\
\hline Gain score & 0.3 & 0.2 & 0.2 & 0.2 \\
\hline $\begin{array}{l}\% \text { household's boys aged } 6-16 \text { in } \\
\text { school) }^{*}\end{array}$ & $n=72$ & $n=35$ & $\mathrm{n}=\mathbf{8 9}$ & $n=62$ \\
\hline $1997^{f}$ & 91 & 93 & 95 & 98 \\
\hline $1999^{\mathrm{e}}$ & 99 & 95 & 97 & 94 \\
\hline Gain score $^{\mathrm{d}, \mathrm{j}}$ & 8 & 1 & 2 & -4 \\
\hline $\begin{array}{l}\text { Average person hours in matched } \\
\text { enterprise last week ** }\end{array}$ & $n=103$ & $\mathrm{n}=77$ & $n=166$ & $n=122$ \\
\hline $1997^{j}$ & 66 & 64 & 59 & 69 \\
\hline $1999^{j}$ & 55 & 62 & 64 & 77 \\
\hline Gain score ${ }^{e}$ & -11 & -1 & 6 & 9 \\
\hline $\begin{array}{l}\text { Av. hours worked by respondent in all } \\
\text { household enterprises last week }\end{array}$ & $n=114$ & $n=79$ & $n=193$ & $n=137$ \\
\hline $1997^{e}$ & 46 & 44 & 46 & 54 \\
\hline $1999^{b, d}$ & 37 & 46 & 42 & 46 \\
\hline Gain score $^{b}$ & -9 & 2 & -4 & -8 \\
\hline $\begin{array}{l}\% \text { that insist on deposit when } \\
\text { extending customer credit } * * * * *\end{array}$ & $n=70$ & $n=52$ & $n=123$ & $n=83$ \\
\hline 1997 & 57 & 69 & 63 & 57 \\
\hline $1999^{c, e}$ & 75 & 60 & 68 & 58 \\
\hline Gain score $e^{a, f}$ & 19 & -10 & 4 & 1 \\
\hline
\end{tabular}




\section{$\%$ Respondents with individual savings accounts ${ }^{* * *}$}

$$
\begin{aligned}
& 1997^{\text {b,d, g }} \\
& 1999^{\text {a, d, g }}
\end{aligned}
$$

Gain score

Average number ways resp. saves ${ }^{* * *}$

$$
n=124
$$

$$
86
$$

91

6

$n=124$

2.1

2.6

.4

$$
\mathrm{n}=\mathbf{8 8}
$$

73

69

$-3$

$n=188$

1.6

2.0

.3

$$
n=194
$$

$n=137$

87

83

68

66

$-4$

$-2$

$n=194$

$\mathrm{n}=137$

1.9

1.6

2.5

2.1

$.4 \quad .5$

*Only covers households with boys aged 6-16 in both 1997 and 1999

${ }^{* *}$ Only covers matched enterprises operating in both 1997 and 1999.

${ }^{* * *}$ Only covers same respondent both years.

****Only covers households with enterprises both years.

The following notes indicate significant differences between affected clients and affected non-clients ${ }^{: a} p \leq .01 ;{ }^{b} p \leq .05$; and ${ }^{\mathrm{c}} \mathrm{p} \leq .10$.

The following notes indicate significant differences between affected clients and other non-clients: ${ }^{d} p \leq .01 ;{ }^{e} p \leq .05$; and ${ }^{f} p \leq$ 10 .

The following indicate significant differences between other clients and other non-clients: ${ }^{g} p \leq .01 ;{ }^{h} p \leq .05 ;{ }^{i} p \leq .10$; and ${ }^{j} p \leq$ .15 . 


\section{Hgrizons}

\section{Appendix D}

\section{Suggestions from the Forum on Microfinance and Households Coping With Illness and Death in Zimbabwe}

\section{Introduction}

The objectives of the one-day forum were to share the findings of the study on the relationship between microfinance and households coping with illness and death in Zimbabwe and provide the opportunity for microfinance institutions (MFIs), HIV/AIDS-related organizations, and donors to discuss the implications of the findings and to network. Thirty-three people participated in the forum. The forum was organized by the Zimbabwe Association of Microfinance Institutions (ZAMFI) and Management Systems International (MSI) and financed by USAID's Horizons Program in cooperation with USAID's AIMS Project. The forum took place in Harare on September $13^{\text {th }}, 2001$.

The main activities were:

- A presentation by Carolyn Barnes (MSI) of the findings of the study on the relationship of microfinance and households coping with illness and death in Zimbabwe, followed by a question period and small group discussions of the most interesting or surprising findings.

- Three groups, each containing a mix of persons from different types of organizations, discussing the implications of the findings in relation to what is currently being done and what else might be done, followed by a report back to all participants.

- Three groups-MFIs, HIV/AIDS-related organizations, and donors-discussing the implications of the findings to what their "sector" might do, followed by a report back to all participants.

A major outcome was the call for more collaboration and information sharing between the different types of groups represented at the forum. This will be facilitated by ZAMFI. 


\section{The Mixed Group Discussions}

The discussions in the three groups elicited the following comments. Time did not permit a discussion of the feasibility and implications of each suggestion. Also, no attempt was made to reach a consensus on the suggestions mentioned below nor to prioritize them. The comments are categorized according to the group to which they were primarily addressed.

\section{Microfinance institutions:}

- Rather than leaving it to individual MFIs, a sector-level approach should be taken to address a number of HIV/AIDS issues. This is important since many organizations are relatively small. As a sector, MFIs should be able to mobilize resources.

- Consider the household, not just individual microentrepreneur, when giving loans. MFIs cannot ignore the fact that money in the household is fungible. They should permit start-up activities and different household members to conduct their economic activities funded by one loan. Upon death of a client, another person from the household should be eligible to fill that person's place in a loan group or with the loan institution, although the person should receive the loan amount for first-time borrowers. MFIs might consider providing loans to household members rather than individuals.

- MFI managers should discuss HIV/AIDS as both a client issue and a management issue. They might consider whether they should have loan officers educate clients on HIV/AIDS issues, have specialists on the staff to educate clients, collaborate with a HIV/AIDS-related organization to provide the education, or provide referrals.

- MFI boards of directors and donors should reconsider their policy/position on the timeframe for MFI financial sustainability, profitability, and productivity. They should think beyond these to consider the implications of HIV/AIDS on MFIs and microentrepreneurs.

- Focus more on delinquency management and how to manage risk. Supporters of MFIs need to be more flexible and understanding about loan loss reserves, given Zimbabwe's HIV/AIDS situation and economic conditions.

- Need new financial products, such as insurance and short-term (e.g., six month) loans for microenterprise activities. Products should be responsive to actual needs and capacities, based on research and experience.

- MFI staff and officers should receive training related to HIV/AIDS so that they are better informed. Clients also need to be educated on HIV/AIDS issues.

- Should study the impact of HIV/AIDS on households and households' coping strategies in order to structure products and services to reach more households.

- Should actively target HIV/AIDS-affected households or individuals, and might provide shortterm loans for the affected households.

- Pilot an approach that incorporates HIV/AIDS messages and reaches HIV/AIDS- affected individuals with microfinance products.

- MFI solidarity groups should be used to help people affected by AIDS.

- Need to modify existing products or develop new products, such as insurance, that would prevent exclusion. 


\section{Hgrizons}

- Should track changing impact of HIV/AIDS on clients and their institutions and focus on the effect of HIV/AIDS on program participation and continuation rates.

\section{Microfinance institutions and HIV/AIDS service organizations:}

- Need to work together to identify the best approaches for combating the denial of HIV/AIDS. MFIs should support and be active in the current momentum to speak out.

- Should strengthen linkages and cooperation between MFIs, HIV/AIDS service organizations (HASOs), donors, and other service organizations. Need a permanent consultative forum to develop strategies to address the MFI-HIV/AIDS nexus and related issues, and to follow-up on progress made. There needs to be more cooperation and collaboration between HIV/AIDS NGOS with income generating programs and MFIs. There should be cross-collaboration of HIV/AIDS service organizations and MFIs; this implies overcoming turf issues and competition for resources. Need to think through a culture of learning and sharing between MFIs, HASOs and donors. Need to have a convergence of thinking among MFIs and HASOs about clients, outreach and programs.

- Need to better understand how program clients are coping with the impact of HIV/AIDS. MFIs/HASOs/donors need to understand who stands to benefit from MFI services and who will benefit from the services of AIDS support organizations. Also need to understand more about youth, their coping strategies, opportunities, and the feasibility of microfinance.

- Should address the situation and demand in rural areas. There is an increase in caregivers and children out of school.

- Need to give a platform for MFI clients and others to express their views on the ways/strategies to combat HIV/AIDS.

\section{HIV/AIDS service organizations:}

- Need more widespread non-financial approaches that focus on infected individuals, such as post-test clubs and treatment for AIDS.

- New, innovative thinking is required to address the gaps in existing programs and approaches. Those falling between the gaps include youth, THE terminally ill, and caregivers who are stretched to the limit.

\section{Donors and HIV/AIDS service organizations:}

- Should be more open to covering the risk of MFIs willing to offer products for HIV-infected individuals. 


\section{The Sector Group Discussions}

Meeting with others from their respective sector, participants from the MFIs, HIV/AIDS service organizations, and donors discussed what else they should be doing as a sector group in addition to ongoing cooperation. Again, no attempt was made to reach a consensus or to prioritize the suggestions. There tended, however, to be general acceptance of these by the sector participants.

\section{Microfinance institutions:}

- ZAMFI members should have a workshop on HIV/AIDS.

- ZAMFI should facilitate networking of MFIs and HASOs to permit them to work together.

- Those MFIs already doing something related to HIV/AIDS should be given a platform to share their experiences. MFIs should share information so that everyone can advance on the learning curve.

- Should collect data; liaise with the Zimbabwe AIDS Council, WHO and others; and come up with an action plan. It is important for all MFIs to have a policy, develop an appropriate culture, and be proactive in establishing ways of addressing the impact of HIV/AIDS on their institutions and clients. It was pointed out that some institutions are not worried about their portfolios because they give grants and are dependent on outside funds.

- Should encourage government to have a sound HIV/AIDS policy.

- Should network with insurance companies in order for clients to be accorded better, affordable premiums for life insurance and health insurance. Also, the sector should lobby insurance companies for affordable premiums to cover MFI loans to borrowers who die.

\section{HIV/AIDS service organizations:}

- Should give affected families microfinance skills and loans.

- Should impart skills to families and people living with HIV/AIDS so that they can work instead of acquiring a culture of dependency upon relief.

- Should encourage families to work together as a team or unit rather than individually on their own income-generating activities.

- Need to be active in breaking the silence about HIV/AIDS.

- Should work in partnership with MFIs in the prevention and mitigation of HIV/AIDS and care of those infected and affected.

- Should consider specialized HIV/AIDS-MFI programs for rural areas targeted especially at women and youth.

- Should be active in promoting prevention of HIV/AIDS education at workplaces. 


\section{Hgrizons}

\section{Donors and other financial support organizations:}

- Should adopt a more realistic policy/stance on the timeframe for MFI financial sustainability that takes into account the situation in Zimbabwe.

- Should provide more resources for MFI technical capacity building, to cover items such as additional staff, piloting new products and expansion into rural areas.

- Should work together to ensure no double dipping: implementing organizations billing more than one donor for the same thing.

- Should adopt a strategy to ensure a general consistency in approaches, rather than fund conflicting approaches and duplicate efforts.

- Need to look for real opportunities to empower people and institutions/organizations to move away from a donor dependency syndrome.

- Should not drive institutional strategies but rather accept that clients' needs are paramount and accept strategies built on client inputs.

\section{Concluding Comments}

The participants agreed that the forum should be considered as a start to networking and collaboration among HASOs, MFIs, and donors. An idea for further sharing of information was proposed. It was agreed that ZAMFI should be the lead facilitator of a permanent consultative forum that would bring interested organizations together. 
Microfinance, Households, and HIVIAIDS

\section{References}

Barnes, Carolyn. 2001. Microfinance Program Clients and Impact: An Assessment of Zambuko Trust, Zimbabwe. AIMS Paper. Washington: Management Systems International. (Available on the AIMS website: www.mip.org.)

Barnes, Carolyn. 2002. Microfinance and Mitigation of the Impacts of HIV/AIDS: An Exploratory Study from Zimbabwe. AIMS Paper. Washington, D.C.: Management Systems International. (Available on the AIMS website: www.mip.org.)

Barnes, Carolyn and Erica Keogh. 1999. An Assessment of the Impact of Zambuko's Microenterprise Program in Zimbabwe: Baseline Findings. AIMS Paper. Washington: Management Systems International. (Available on the AIMS website: www.mip.org.)

Chen, Martha A. and Donald Snodgrass. 2001. Managing Resources, Activities and Risks in Urban India: The Impact of SEWA Bank. AIMS Paper. Washington: Management Systems International. (Available on the AIMS website: www.mip.org.)

Christen, Robert Peck. 2000. Commercialization and Mission Drift: The Transformation of Microfinance in Latin America. Washington: Consultative Group to Assist the Poor.

Dunford, Christopher. 2001. Sustainable Integration of Microfinance with Education in Health, Family Planning and HIV/AIDS Prevention for the Poorest Entrepreneurs. A discussion paper done by C. Dunford of Freedom from Hunger, commissioned by the Microcredit Summit Campaign.

Dunn, Elizabeth and J. Gordon Arbuckle Jr. 2001. The Impacts of Microcredit: A Case Study from Peru. AIMS Paper. Washington: Management Systems International. (Available on the AIMS website: www.mip.org.)

McPherson, Michael A. 1998. Zimbabwe: A Third Nationwide Survey of Micro and Small Enterprises. Report prepared for USAID/Zimbabwe by Price Waterhouse Coopers.

Reichardt, Charles S. 1979. "The Statistical Analysis of Data from Nonequivalent Group Designs." In Quasi-Experimentation: Design and Analysis Issues for Field Settings. Thomas D. Cook and Donald T. Campbell, eds. Chicago: Rand McNally.

Sebstad, Jennefer and Monique Cohen. 2001. Microfinance, Risk Management, and Poverty. Washington: Consultative Group to Assist the Poor, World Bank. (Available on the AIMS website: www.mip.org.)

UNAIDS and WHO. 2000. Zimbabwe Epidemiological Fact Sheet on HIV/AIDS and Sexually Transmitted Diseases. 2000 Update. 


\section{Hgrizons}

USAID. n.d. Microenterprise Development Policy Paper. Washington: U.S. Agency for International Development. 


\section{Hgrizons}

Horizons is a global operations research program designed to:

- Identify and test potential strategies to improve HIVIAIDS prevention, care, and support programs and service delivery.

- Disseminate best practices and utilize findings with a view toward scaling up successful interventions.

\section{Population Council}

Horizons is implemented by the Population Council in collaboration with

- International Center for Research on Women (ICRW)

- International HIVIAIDS Alliance

- Program for Appropriate Technology in Health (PATH)

- Tulane University

- Family Health International (FHI)

- Johns Hopkins University

For more information, please contact:

Horizons Program, Communications Unit 4301 Connecticut Avenue, NW Suite 280 Washington, DC 20008 USA

Tel: 202-237-9400

Fax: 202-237-8410

Email: horizons@pcdc.org www.popcouncil.org/horizons 